\title{
Forecasting index changes in the German DAX family
}

\author{
Friedrich-Carl Franz ${ }^{1}$
}

Revised: 30 January 2020 / Published online: 18 February 2020

(c) The Author(s) 2020

\begin{abstract}
Combining market data with a publicly available monthly snapshot of Deutsche Börse's index ranking list, I create a model that predicts index changes in the DAX, MDAX, SDAX, and TecDAX from 2010 to 2019 before they are officially announced. Even though I empirically show that index changes are predictable, they still earn sizeable post-announcement 1-day abnormal returns up to $1.42 \%$ and $-1.54 \%$ for promotions and demotions, respectively. While abnormal returns are larger in smaller stocks, I find no evidence that they are related to funding constraints or additional risk for trading on wrong predictions. A trading strategy that trades according to my model yields an annualized Sharpe ratio of 0.83 while being invested for just 4 days a year.
\end{abstract}

Keywords Index rebalancing $\cdot$ Passive investment $\cdot$ Index effect $\cdot$ Index investing $\cdot$ Trading strategy

JEL Classification $\mathrm{G} 12 \cdot \mathrm{G} 14$

\section{Introduction}

Index-linked or the so-called passive investments are growing steadily every year. ${ }^{1}$ One related but unsettled research question is the existence of the index effect, i.e., abnormal returns of additions and deletions around index rebalancings. Recent results in the literature [see e.g., Kappou (2018)] show that abnormal returns are nowadays flat on the rebalancing date and limited to the day following the announcement. This makes exploitation difficult and the market supposedly more efficient. For example, Fig. 1 shows the intraday return chart of two recent DAX pro- and demotions on the day following the respective index change announcement by Deutsche Börse. The opening gap, e.g., up to $4 \%$ for Covestro, could only be collected by arbitrageurs if they had known the index changes before their respective announcement. $^{2}$ In this paper, I empirically establish that index changes - at least in Germany-are relatively easy to predict making the index effect still exploitable. A trading strategy that trades on the predictions of my model has an

Friedrich-Carl Franz

franz@finance.uni-frankfurt.de

1 Goethe University Frankfurt, House of Finance Room 2.73, Theodor-W.-Adorno Platz 3, 60323 Frankfurt, Germany annualized Sharpe ratio of 0.83 while being invested for only four days a year.

Importantly, I examine index changes within the German DAX family, i.e., the DAX, MDAX, SDAX, and TecDAX, from 2010 to 2019 with respect to their ex-ante predictability and abnormal returns around their announcement. This yields two major contributions to the index effect literature. First, this paper islto my knowledgelthe first paper that empirically demonstrates the predictability of index changes. Fernandes and Mergulhao (2016) create a probit model to predict FTSE 100 changes but focus on the ex-post inherited probabilities and do not discuss the performance of their model with respect to real-world predictions. Although most index methodologies are rule-based and publicly available, forecasting index changes with data that were available to the public at the respective point in time is challenging. For example, to predict German DAX changes one would need to calculate the free float exactly analogous to Deutsche Börse's methodology and keep track of all index-eligible stocks trading on Xetra at every historic rebalancing date. I overcome these difficulties by using the publicly available

\footnotetext{
${ }^{1}$ For example, see https://www.morningstar.com/blog/2018/03/12/ fund-flows-charts.html.

2 Note that the last DAX changes, which were announced on the September 4, 2019, exhibited the opposite behavior, i.e., the demotion (promotion) Thyssenkrupp (MTU Aerio Engine) was the best (worst) performing stock in their respective index on the following day.
} 


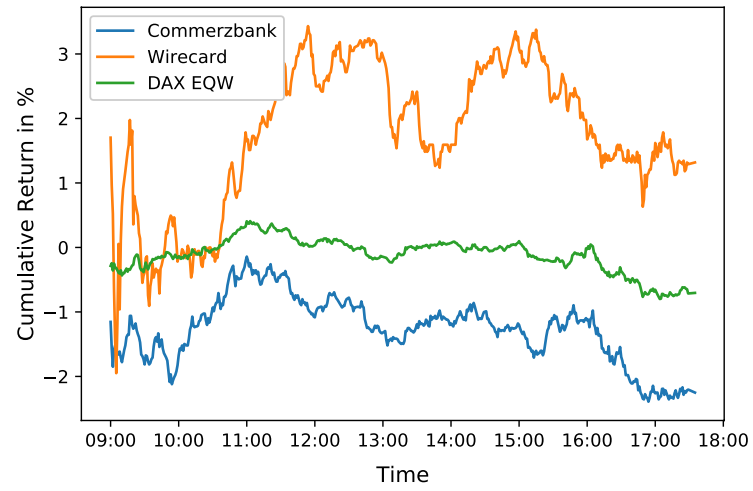

(I) 2018-09-06

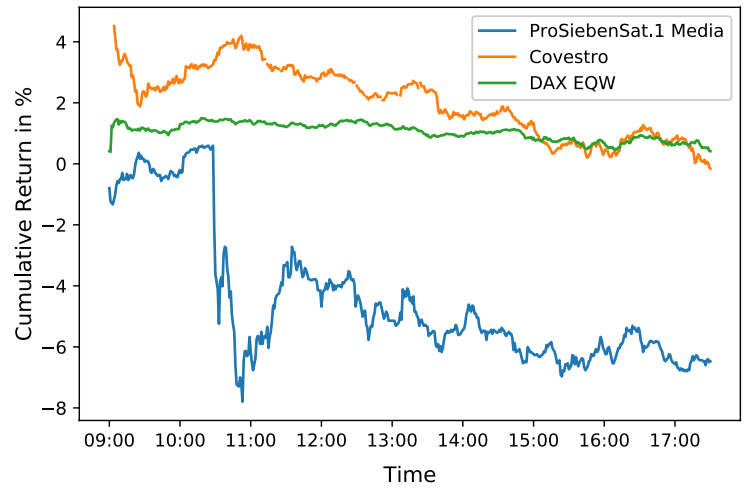

(II) 2018-03-06
Fig. 1 DAX AD+1-intraday cumulative returns. This figure shows cumulative intraday returns during the $\mathrm{AD}+1$ of the DAX addition (deletion) Commerzbank (Wirecard) on the left and of the DAX addi- tion (deletion) ProSiebenSat.1 Media (Covestro) on the right. DAX EQW refers to an equally weighted portfolio of DAX constituents ranking lists for the DAX family, which are a monthly snapshot of Deutsche Börse's ranking of the German equity universe according to their data and methodology. This unique service makes the German DAX family the prime habitat for a study on anticipating index changes. Combining the ranking list with standard market data, I create a model that, for example, correctly predicts $71 \%$ of DAX changes.

Second, having empirically established that index changes are predictable, I examine abnormal returns conditional to the prediction of my model. The results show that more surprising changes are not related to higher abnormal return as, e.g., argued and shown in the merger market by Song and Walkling (2000). Abnormal returns of changes that were correctly predicted are of similar magnitude compared to abnormal returns of changes that were not predicted. Instead, limits to arbitrage theories (Gromb and Vayanos 2010) or investor (in)attention (Barber and Odean 2008) might help to explain the market inefficiency. That is, larger stocks tend to earn lower abnormal returns. However, even in the largecap index DAX, correctly predicted demotions earn a 1-day average abnormal return of $-1.63 \%$. Funding constraints do not seem to play a role as abnormal returns seem to be lower when the VDAX is higher. Additionally, arbitrageurs do not face the additional risk of getting it wrong, i.e., the abnormal gains of trading correctly predicted changes are not offset by abnormal losses of trading falsely predicted changes.

The literature on the index effect in the equity markets is extensive, and Afego (2017) offers an excellent survey. Since the first papers on the index effect by Goetzmann and Garry (1986), Shleifer (1986), and Harris and Gurel (1986) abnormal returns have shifted from the rebalancing date to the announcement date. Consequently, Kappou (2018) concludes that market participants are nowadays well prepared for large index flows. Green and Jame (2011) support that by showing that index trackers do not wait until the rebalancing date to implement the announced index changes, but already trade between the announcement and rebalancing date. Therefore, this paper focuses on the announcement day.

Abnormal returns following the index change announcement are also found recently by others, such as Yu et al. (2015) and Biktimirov and Xu (2019) for the USA., and Chen et al. (2016) for the international equity markets. Chen et al. (2004) find higher abnormal returns for additions than for deletions in the S\&P 500 and link the difference to a change in investor awareness. My result does not support their conclusion as abnormal returns of pro- and demotions are of similar magnitude. Lee et al. (2008) document significant abnormal returns for S\&P 500 additions during the post-trading session after the announcement. Other studies that find abnormal post-announcement returns include Harris and Gurel (1986), Goetzmann and Garry (1986), Shleifer (1986), Jain (1987), and Beneish and Whaley (1996) for the S\&P 500, Petajisto (2011) and Chang et al. (2014) for the Russel2000, Deininger et al. (2000) for the German DAX and MDAX, Doeswijk (2005) for the AEX index, Chakrabarti et al. (2005) for international MSCI indices, Liu (2006) and Liu (2011) for the Nikkei225, Mazouz and Saadouni (2007) and Mase (2007) for the FTSE100, Qiu and Pinfold (2007) for the ASX300, and Yun and Kim (2010) for the KOSPI 200. Similar to the German DAX, many of these indices are based on a publicly available rule-based methodology. Therefore, the results in this paper should be generalizable to the aforementioned international indices.

The pre-announcement period has also received attention in the literature. Zdorovtsov et al. (2017) arguelon the example of the Russell 3000|that speculators do not only trade to gain on price movements but that they actively try to push stocks into indices. Mase (2007) and Fernandes and Mergulhao (2016) find evidence of anticipatory trading in the FTSE 100, which has a very straightforward methodology. 
Predicting index changes is also common among practitioners. For example, Serkan Bartir, the head of portfolio management of Blackrock in Germany, states that index changes are no surprise anymore and that forecasts by brokers are released weeks before their announcement. ${ }^{3}$ He also says that Blackrock waits until the rebalancing date to implement the changes, which could be explained by the priority of tracking error over outperformance of index fund managers as argued by Blume and Edelen (2004). Nonetheless, arbitrageurs that do not face such constraints should step in and front-run the temporary mispricing in predictable index changes. Consequently, the high abnormal returns found in this paper pose a challenge for efficient markets and support theories from, e.g., Duffie (2010) that arbitrageurs face restrictions, such as slow-moving capital, that forces them to forgo profitable opportunities.

The paper is structured as follows. Section 2 explains the index methodologies, introduces the data, and discusses the prediction model. Section 3 presents and discusses the results. Section 4 concludes.

\section{Data and methodology}

Deutsche Börse decides on index membership within the index-eligible stocks based on free floating market capitalization and turnover. ${ }^{4}$ Additional criteria determine whether membership in the DAX family is actually possible. For example, to be able to become a member of the DAX, MDAX, SDAX, or TecDax, a stock must be listed in Deutsche Börse's Prime Standard, be continuously traded on Xetra, and must have its legal or operating headquarter in Germany. Among the index-eligible companies, Deutsche Börse creates a monthly ranking list to determine the respective index membership. For instance, a company is added to the DAX if it ranks below 26 in market capitalization and turnover. Therefore, index membership is completely determined by the ranking list and if an investor can predict the ranking list, she can predict index changes. The list is created upon data from the last trading day of the previous month but published together with the index change announcements after the close of trading on the third trading day of the month. Consequently, arbitrageurs that want to front-run the index change announcements have 3 days between the cutoff for the final data collection and announcement. I call the announcement day (AD) and the trading day after the announcement $(\mathrm{AD}+1)$. Note that neither the ranking list

\footnotetext{
${ }^{3}$ See p. 40 in the July 2019 edition of the Rendite Magazin of the Börsen-Zeitung.

${ }^{4}$ See https://www.dax-indices.com/document/Resources/Guides/ Guide_Equity_Indices.pdf for the detailed up-to-date methodology.
}

nor index changes are available to the public before their announcement.

Since 2010 Deutsche Börse made several changes to their index methodology, such as varying the cutoffs for index changes. For example, in 2018, they increased the number of index constituents from 50 to 60 and from 50 to 70 for the MDAX and SDAX, respectively. This methodology change was announced well in advance, ${ }^{5}$ and I exclude these changes from the sample because it is an extraordinary adjustment with many changes that would make the results non-representative of a regular index change. However, all methodology changes are incorporated into the forecasting model. Before September 2016, Deutsche Börse used the so-called soft criteria, such as industry membership, to alter index changes via a discretionary overlay. They switched to a fully transparent methodology because these soft criteria were hardly used and most often the actual changes were identical to the changes derived by the purely rule-driven methodology. Therefore, arbitrageurs can forecast the ranking list and ultimately index changes by recalculating the rankings using the official methodology created upon free floating market capitalization and turnover. Furthermore, arbitrageurs must keep constantly track of new and delisted companies and their potential index eligibility.

Index changes are very sensitive to the data of the complete index universe, i.e., arbitrageurs must get the whole ranking right and not just the data of one potential change. For example, a promotion can be triggered by, e.g., the rise of market capitalization of that promotion or by the decline of market capitalization by another stock that consequently has become a demotion. However, getting the same data that Deutsche Börse uses is not straightforward. For example, the number of eligible shares or the free float in standard databases, such as Bloomberg or Compustat, might be very similar but not identical to the version Deutsche Börse uses. Consequently, I was unable to recreate the ranking list by relying solely on data from Bloomberg and Compustat and instead, use the official ranking list of the previous month and mix it with a custom ranking based upon on publicly available market data.

Specifically, for every last trading day in a month $t, \mathrm{I}$ rank the stocks that were part of the official ranking list in the month $t-1$ according to the index methodology based on data from Bloomberg and Compustat. I call these ranks customranks. Then, I calculate the change of these customranks for stock $i$ between the months. As shown in Eq. 1, the difference between the custom ranking between month $t$ and $t-1$, which is based on market data, is then added to the

\footnotetext{
${ }^{5}$ See https://deutsche-boerse.com/dbg-de/media/pressemitteilun gen/Deutsche-B-rse-beschlie-t-Regel-nderungen-f-r-Indizes-MDAXSDAX-und-TecDAX-147700.
} 
official Deutsche Börse rank of the prior month to obtain the final rank that I use to predict index changes.

finalrank $_{i, t}=$ officialrank $_{i, t-1}+\left(\right.$ customrank $_{i, t}-$ customrank $\left._{i, t-1}\right)$

This approach has the advantage that market data must not match Deutsche Börse data exactly in order to make meaningful predictions. For example, if the free float in Bloomberg is different from the free float Deutsche Börse uses, the forecasted ranking would still be accurate as long as the difference stays constant between the months. Furthermore, I do not have to track the whole German stock universe at every rebalancing date because it is given in the ranking list of the previous month.

Fernandes and Mergulhao (2016) use a probit model to forecast FTSE100 changes. I prefer my methodology for the following four reasons. First, the methodology of the FTSE100 is much simpler than the DAX' methodology as it only relies on a ranking of unadjusted market capitalization compared to the many different interdependencies in the DAX' methodology. This eases the regression design and lowers the requirements on data quality significantly. Second, there is only 1 day between the data cutoff and announcement date in the FTSE 100. In contrast, arbitrageurs in the DAX have 3 days between the data cutoff and the announcement date to position for the changes. Consequently, there is no uncertainty with respect to changing prices due to market movements and a probability-driven approach seems unreasonable to me. Third, and in contrast to Fernandes and Mergulhao (2016), I include all changes due to corporate actions to obtain a realistic setup. This is an important distinction because corporate actions can significantly alter the ranking and thus predictions. Fourth, my equity universe is determined ex-ante due to the publicly available ranking list and not constructed ex-post using the actual changes. This makes my setup free of any backwardlooking bias.

The historical index constituents and the monthly ranking list are obtained directly from the public section of Deutsche Börse's website. ${ }^{6}$ Daily DAX, MDAX, SDAX, and TecDAX index returns and free float for index constituents are obtained from Bloomberg. Daily closing prices and shares outstanding are from Compustat, which is accessed via the Wharton Research Data Services (WRDS). Intraday returns are obtained from the Deutsche Boörse public dataset. ${ }^{7}$ I merge Compustat, Deutsche Börse, and Bloomberg data via the stock's ISIN. Total returns are calculated using Compustat's dividend and total return adjustment factors. Table 1 shows the descriptive statistics of the sample at the

\footnotetext{
${ }^{6}$ See https://www.dax-indices.com/ressourcen.

${ }^{7}$ See https://registry.opendata.aws/deutsche-boerse-pds/.
}

respective $\mathrm{AD}$ for each stock. The total return, i.e., the return before subtracting the benchmark return, is $-0.68 \%$ and $+0.73 \%$ for DAX promotions on the AD and the AD+1, respectively. The mean unadjusted market capitalization ranges from 241 EUR million for demotions from the TecDAX to 13.4 EUR billion for promotions to the DAX. Thus, the separation into the four segments yields insights into the announcement effect with respect to stock size and liquidity.

I do not use a market or multi-factor model, such as the Fama and French (1993) model, to create abnormal returns because oftentimes additions are newly listed companies and hence are not publicly traded long enough to estimate reliable coefficients. Therefore, abnormal returns are calculated as in Eq. 2 whereby $\mathrm{R}$ is the total return of stock $i$ at day $t$ and $j$ refers to the respective index of stock $i$ at day $t$. For example, $j$ would be the DAX if stock $i$ is a pro- or demotion in the DAX.

$A R_{i, t}=R_{i, t}-R_{j, t}$

\section{Results and discussion}

Table 2 shows the performance of the forecasting model. It correctly predicts about $45 \%$ of the actual changes, i.e., 108 out of 228 , and $27 \%$ of the predicted changes are false positives, i.e., 40 out of 148 . The performance is much better in the DAX (71\% and 16\%) and MDAX (63\% and 19\%) than in the SDAX (30\% and 40\%). This is expected because first, the SDAX contains the smallest stocks and hence the data availability and quality are likely to be the poorest. Second, changes due to IPOs or delistings are only predictable if they are already covered in the ranking list of the prior month. That is not always the case and since SDAX constituents are affected most by these corporate actions, predicting them is the most difficult. Fernandes and Mergulhao (2016) arelto the best of my knowledgel the only paper that tries to predict index changes, and the authors focus on an ex-post evaluation. Consequently, there is no benchmark for my model in the literature. Nonetheless, it seems to predict at least the larger index changes reasonably well and thus, empirically establishes that index changes can be predicted before their announcement.

Arbitrageurs who want to profit from a potential announcement effect are likely to trade near the close of the $\mathrm{AD}$ because it is closest to the announcement and hence trading on the $\mathrm{AD}$ would expose the arbitrageur to less risk than trading before it and holding the potential announcement over several days or even weeks. The cutoff for the data collection to determine index membership is 3 days prior to the announcement and hence abnormal returns on the $\mathrm{AD}$ 
Table 1 Descriptive statistics

\begin{tabular}{|c|c|c|c|c|c|c|c|c|c|c|}
\hline & \multicolumn{5}{|c|}{ Promotion } & \multicolumn{5}{|c|}{ Demotion } \\
\hline & Price & Market Cap & Free Float & Return AD & Return AD+1 & Price & Market Cap & Free Float & Return AD & Return AD+1 \\
\hline \multicolumn{11}{|l|}{$D A X$} \\
\hline Count & 7.00 & 7 & 7.00 & 7.00 & 7.00 & 7.00 & 7 & 7.00 & 7.00 & 7.00 \\
\hline Mean & 76.56 & 13465 & 82.54 & -0.68 & 0.73 & 35.23 & 6573 & 72.35 & 0.46 & -0.75 \\
\hline Std & 52.09 & 6120 & 18.68 & 3.01 & 2.16 & 21.30 & 3049 & 30.58 & 2.32 & 3.61 \\
\hline Min & 29.57 & 5158 & 47.20 & -5.75 & -1.27 & 8.30 & 2962 & 24.97 & -2.72 & -6.39 \\
\hline $25 \%$ & 44.69 & 9101 & 74.28 & -1.88 & -1.15 & 22.82 & 3997 & 51.77 & -0.91 & -2.87 \\
\hline $50 \%$ & 61.99 & 13780 & 93.00 & -1.26 & 0.23 & 28.13 & 6554 & 79.99 & 0.20 & -1.15 \\
\hline $75 \%$ & 85.25 & 17160 & 94.56 & 1.33 & 2.32 & 46.14 & 9054 & 98.97 & 2.08 & 2.19 \\
\hline Max & 184.50 & 22798 & 99.93 & 3.33 & 3.81 & 72.30 & 10390 & 100.00 & 3.42 & 3.61 \\
\hline Skewness & 1.80 & 0 & -1.27 & -0.39 & 0.59 & 0.73 & 0 & -0.66 & 0.00 & -0.34 \\
\hline Kurtosis & 3.65 & -1 & 1.19 & 0.22 & -1.59 & 0.30 & -2 & -1.27 & -1.14 & -1.03 \\
\hline \multicolumn{11}{|l|}{$M D A X$} \\
\hline Count & 35.00 & 34 & 34.00 & 35.00 & 35.00 & 35.00 & 34 & 34.00 & 35.00 & 35.00 \\
\hline Mean & 48.16 & 4694 & 54.82 & -0.03 & 0.13 & 60.65 & 2442 & 49.97 & -0.39 & -0.80 \\
\hline Std & 83.74 & 4099 & 24.68 & 1.77 & 1.83 & 100.81 & 2718 & 26.18 & 2.46 & 2.67 \\
\hline Min & 4.17 & 442 & 9.36 & -5.45 & -4.43 & 1.30 & 130 & 4.97 & -7.84 & -6.23 \\
\hline $25 \%$ & 17.47 & 2064 & 32.26 & -0.61 & -0.74 & 10.95 & 945 & 29.62 & -0.88 & -1.71 \\
\hline $50 \%$ & 30.21 & 3263 & 54.65 & 0.00 & 0.37 & 25.20 & 1551 & 45.94 & -0.34 & -0.61 \\
\hline $75 \%$ & 44.50 & 6063 & 71.23 & 0.99 & 1.24 & 65.88 & 3088 & 65.80 & 0.60 & 0.50 \\
\hline Max & 510.00 & 17286 & 100.00 & 3.35 & 2.65 & 542.65 & 13002 & 100.00 & 7.30 & 4.74 \\
\hline Skewness & 5.21 & 1 & 0.27 & -1.00 & -0.88 & 3.64 & 2 & 0.45 & -0.35 & -0.22 \\
\hline Kurtosis & 29.20 & 2 & -0.87 & 2.11 & 0.41 & 15.64 & 7 & -0.69 & 4.63 & 0.28 \\
\hline \multicolumn{11}{|l|}{$S D A X$} \\
\hline Count & 39.00 & 39 & 38.00 & 40.00 & 39.00 & 41.00 & 41 & 40.00 & 41.00 & 41.00 \\
\hline Mean & 29.47 & 1894 & 58.98 & 0.01 & 0.89 & 22.26 & 454 & 61.08 & -1.01 & -0.98 \\
\hline Std & 21.78 & 2725 & 27.77 & 2.07 & 2.49 & 20.99 & 593 & 26.10 & 7.14 & 2.88 \\
\hline Min & 2.51 & 118 & 9.55 & -5.53 & -3.05 & 0.04 & 4 & 14.37 & -43.90 & -15.22 \\
\hline $25 \%$ & 16.32 & 314 & 37.92 & -0.82 & -0.22 & 4.90 & 170 & 42.56 & -1.05 & -1.47 \\
\hline $50 \%$ & 24.61 & 630 & 61.10 & -0.03 & 0.34 & 15.60 & 272 & 55.77 & -0.19 & -0.48 \\
\hline $75 \%$ & 33.92 & 2410 & 84.34 & 1.10 & 1.45 & 32.62 & 438 & 87.81 & 0.71 & 0.08 \\
\hline Max & 91.50 & 12965 & 100.00 & 5.35 & 10.03 & 73.75 & 3377 & 100.00 & 5.37 & 3.45 \\
\hline Skewness & 1.28 & 3 & -0.07 & -0.08 & 1.62 & 1.14 & 3 & 0.08 & -5.64 & -3.28 \\
\hline Kurtosis & 1.22 & 7 & -1.20 & 0.99 & 4.19 & 0.49 & 15 & -1.14 & 34.65 & 15.17 \\
\hline \multicolumn{11}{|l|}{ TecDAX } \\
\hline Count & 25.00 & 24 & 24.00 & 25.00 & 25.00 & 25.00 & 23 & 22.00 & 25.00 & 25.00 \\
\hline Mean & 31.06 & 2108 & 65.99 & 0.79 & 1.82 & 28.07 & 241 & 77.29 & -0.19 & -1.33 \\
\hline Std & 39.00 & 7223 & 26.82 & 2.47 & 3.19 & 59.30 & 201 & 17.43 & 3.38 & 4.13 \\
\hline Min & 3.50 & 132 & 10.90 & -3.94 & -4.09 & 0.25 & 44 & 45.87 & -8.65 & -12.01 \\
\hline $25 \%$ & 8.81 & 206 & 43.58 & -0.70 & -0.02 & 3.35 & 125 & 64.17 & -1.28 & -2.86 \\
\hline $50 \%$ & 16.49 & 365 & 71.17 & 0.78 & 1.78 & 7.00 & 174 & 78.02 & -0.30 & -0.52 \\
\hline $75 \%$ & 44.80 & 579 & 89.83 & 2.35 & 3.51 & 20.61 & 317 & 91.30 & 1.31 & 0.72 \\
\hline Max & 183.40 & 35500 & 100.00 & 5.28 & 10.22 & 294.50 & 947 & 100.00 & 7.19 & 7.19 \\
\hline Skewness & 2.81 & 5 & -0.61 & -0.05 & 0.68 & 4.10 & 2 & -0.18 & -0.26 & -1.00 \\
\hline Kurtosis & 9.49 & 22 & -0.62 & -0.68 & 0.96 & 18.45 & 6 & -1.27 & 1.18 & 2.09 \\
\hline
\end{tabular}

This table shows the descriptive statistics of promotions and demotions. Price is in euro, and Market Cap refers to the unadjusted market capitalization in million euro on the respective announcement day of the index constituent change. The free float is in percent, and the return refers to the daily return in percent. The sample period is from 2010 to 2019 
Table 2 Actual and predicted changes by category

\begin{tabular}{lcccc}
\hline Index & Actual changes & $\begin{array}{c}\text { Correctly } \\
\text { predicted }\end{array}$ & Not predicted & $\begin{array}{c}\text { Wrongly } \\
\text { predicted }\end{array}$ \\
\hline DAX & 14 & 10 & 4 & 2 \\
MDAX & 70 & 44 & 26 & 10 \\
SDAX & 92 & 28 & 64 & 19 \\
TecDAX & 52 & 26 & 26 & 9 \\
Total & 228 & 108 & 120 & 40 \\
\hline
\end{tabular}

This table shows the number of predictions of pro- and demotions within the DAX family from 2010 to 2019 . Predictions are based on a forecast model described in Sect. 2. Correctly predicted changes are true positives, not predicted false negatives, and wrongly predicted changes are false positives

cannot be due to some type of index gaming, i.e., bidding prices up to push a stock in the larger index, as argued in Zdorovtsov et al. (2017) for the Russell indices. Table 3 displays that abnormal returns of the index changes on that day are relatively small. However, promotions and demotions have the expected signs. That is, promotions (demotions) earn a positive (negative) 33bp (25bp) abnormal return on the AD. While only promotions to the MDAX and TecDAX are at most weakly significant, the evidence on the AD indicates that there seems to be at least some pre-announcement speculation by sophisticated investors. Moreover, the magnitude of the abnormal return of changes that have not been predicted by my forecasting model is even larger, which might be due to chance or due to investors having a superior approach compared to my simple model for predicting index changes.

Figure 2 displays abnormal returns on the $\mathrm{AD}+1$. Correctly predicted changes are in green, actual changes that have not been predicted (false negatives) in red, and falsely predicted changes (false positives) in blue. Table 4 shows the corresponding $p$ values. The magnitude of abnormal returns is much larger on the $\mathrm{AD}+1$ than on the $\mathrm{AD}$. Combining all actual promotions (demotions) yields a highly significant positive (negative) 82bp (98bp) whereby the strongest moves occur in TecDAX and SDAX changes. Therefore, the announcement effect of index changes seems to still be present in the German equity market, which is consistent with international findings, such as in Kappou (2018) for the S\&P 500 or in Biktimirov and Xu (2019) for the NASDAQ-100.

Motivated by Song and Walkling (2000) who link takeover probabilities to abnormal returns, I investigate whether unexpected changes have higher abnormal returns. That is, I would expect the changes that were not predicted by the model to have larger abnormal returns than changes that were predicted. However, Table 5 shows that the average of the differences between correctly and not predicted changes has no clear message. While, for example, TecDAX demotions that are not predicted earn a much larger negative abnormal return that is not true for MDAX demotions and DAX promotions. Therefore, it does not seem that more surprising index changeslat least in comparison with my modell earn higher abnormal returns.

There are at least two rational theories [see, e.g., Gromb and Vayanos (2010)] that might explain these abnormal returns. First, arbitrageurs might be able to collect abnormal returns because they are exposed to additional risk, i.e., they collect a risk premium. Second, real-world limits to arbitrage, such as funding constraints, trading costs, or short-selling restrictions make real-world exploitation impossible or at least unprofitable.

If arbitrageurs were earning a profit in predictable changes, theory would suggest that these profits reflect a risk premium for bearing the risk of falsely predicting changes resulting in a loss. My empirical hypothesis does not support this. As shown in Table 4, wrongly predicted changes are insignificant and of the same sign as actual changes, which indicates that speculators do not take a large hit by falsely predicted changes. That is, a speculator that is long predicted promotions and short predicted demotions would only lose on average $17 \mathrm{bp}$ in the falsely predicted changes compared to a gain of $1.8 \%$ in the correctly predicted changes.

The second rational explanation argues that the shown abnormal profits are mostly paper gains but hardly exploitable in practice. Abnormal returns for demotions are hardly larger than for promotions, which indicate that short-sell restrictions are not the cause of these returns. However, especially TecDAX changes are rather small with a median unadjusted market capitalization of 365 million euro and 174 million euro for pro-and demotions, respectively (see Table 1). Thus, they are likely to be more illiquid. Indeed, the results in Table 4 show that abnormal returns are the highest in the TecDAX followed by the SDAX, which changes are mostly smaller stocks, too. While the DAX results have to be treated with care due to the small sample, abnormal returns for MDAX changes are present but considerably smaller than in the TecDAX and SDAX.

To test the influence of stock size on abnormal returns, I regress abnormal returns on the $\mathrm{AD}+1$ on market capitalization. Moreover, I include the VDAX in the regression, which is a proxy for tighter funding constraints (see, e.g., Nagel (2012)). That is, a higher VDAX is related to tighter funding and hence less activity of arbitrageurs. Specifically, I use the level of the VDAX at day $t$ to estimate the following regression whereby $D_{i}^{P M}$ is a 1 if stock $\mathrm{i}$ is a promotion at day $t$ and 0 if it is a demotion at day $t$.

$$
\begin{aligned}
\operatorname{return}_{i, t}= & \alpha+\beta_{1} D_{i, t}^{P M}+\beta_{2} \text { MarketCap }_{i, t} \\
& +\beta_{3} D_{i, t}^{P M} * \operatorname{MarketCap}_{i, t} \\
& +\beta_{4} \operatorname{VDAX}_{t}+\beta_{5} D_{i, t}^{P M} * \operatorname{VDAX}_{t}+\epsilon_{i, t}
\end{aligned}
$$


Table 3 Abnormal returns on the AD by category—-statistics

\begin{tabular}{|c|c|c|c|c|c|c|c|c|}
\hline & \multicolumn{4}{|l|}{ Promotion } & \multicolumn{4}{|l|}{ Demotion } \\
\hline & Actual changes & $\begin{array}{l}\text { Correctly } \\
\text { predicted }\end{array}$ & Not predicted & Wrongly predicted & Actual changes & $\begin{array}{l}\text { Correctly } \\
\text { predicted }\end{array}$ & Not predicted & Wrongly predicted \\
\hline \multicolumn{9}{|l|}{$D A X$} \\
\hline Mean & $\begin{array}{l}-0.90 \\
(0.25)\end{array}$ & $\begin{array}{l}-0.80 \\
(0.44)\end{array}$ & $\begin{array}{l}-1.15 \\
(0.54)\end{array}$ & $\begin{array}{l}-0.04 \\
(-)\end{array}$ & $\begin{array}{l}0.24 \\
(0.83)\end{array}$ & $\begin{array}{l}0.58 \\
(0.72)\end{array}$ & $\begin{array}{l}-0.60 \\
(0.21)\end{array}$ & $\begin{array}{l}0.28 \\
(-)\end{array}$ \\
\hline Median & $\begin{array}{l}0.06 \\
(0.50)\end{array}$ & $\begin{array}{l}0.06 \\
(0.69)\end{array}$ & $\begin{array}{l}-1.15 \\
(0.65)\end{array}$ & $\begin{array}{l}-0.04 \\
(0.32)\end{array}$ & $\begin{array}{l}-0.40 \\
(0.87)\end{array}$ & $\begin{array}{l}-0.27 \\
(0.69)\end{array}$ & $\begin{array}{l}-0.60 \\
(0.18)\end{array}$ & $\begin{array}{l}0.28 \\
(0.32)\end{array}$ \\
\hline $\begin{array}{l}N \\
M D A X\end{array}$ & 7 & 5 & 2 & 1 & 7 & 5 & 2 & 1 \\
\hline Mean & $\begin{array}{l}0.52 * * \\
(0.03)\end{array}$ & $\begin{array}{l}0.42 \\
(0.19)\end{array}$ & $\begin{array}{l}0.70 * * \\
(0.04)\end{array}$ & $\begin{array}{l}0.89 \\
(0.18)\end{array}$ & $\begin{array}{l}0.17 \\
(0.59)\end{array}$ & $\begin{array}{l}0.50 \\
(0.26)\end{array}$ & $\begin{array}{l}-0.33 \\
(0.43)\end{array}$ & $\begin{array}{l}-1.76 \\
(0.33)\end{array}$ \\
\hline Median & $\begin{array}{l}0.36^{* *} \\
(0.04)\end{array}$ & $\begin{array}{l}0.02 \\
(0.35)\end{array}$ & $\begin{array}{l}0.98 * \\
(0.06)\end{array}$ & $\begin{array}{l}1.04 \\
(0.14)\end{array}$ & $\begin{array}{l}-0.11 \\
(0.92)\end{array}$ & $\begin{array}{l}0.13 \\
(0.50)\end{array}$ & $\begin{array}{l}-0.14 \\
(0.51)\end{array}$ & $\begin{array}{l}-1.12 \\
(0.25)\end{array}$ \\
\hline $\begin{array}{l}N \\
S D A X\end{array}$ & 35 & 23 & 12 & 4 & 35 & 21 & 14 & 6 \\
\hline Mean & $\begin{array}{l}0.22 \\
(0.40)\end{array}$ & $\begin{array}{l}0.29 \\
(0.60)\end{array}$ & $\begin{array}{l}0.20 \\
(0.52)\end{array}$ & $\begin{array}{l}0.13 \\
(0.85)\end{array}$ & $\begin{array}{l}-0.83 \\
(0.47)\end{array}$ & $\begin{array}{l}0.01 \\
(0.99)\end{array}$ & $\begin{array}{l}-1.37 \\
(0.46)\end{array}$ & $\begin{array}{l}-1.23 \\
(0.14)\end{array}$ \\
\hline Median & $\begin{array}{l}0.13 \\
(0.45)\end{array}$ & $\begin{array}{l}0.42 \\
(0.51)\end{array}$ & $\begin{array}{l}0.11 \\
(0.63)\end{array}$ & $\begin{array}{l}0.44 \\
(0.88)\end{array}$ & $\begin{array}{l}-0.43 \\
(0.69)\end{array}$ & $\begin{array}{l}-0.52 \\
(0.44)\end{array}$ & $\begin{array}{l}0.32 \\
(0.80)\end{array}$ & $\begin{array}{l}-0.79 \\
(0.35)\end{array}$ \\
\hline $\begin{array}{l}N \\
T e c D A X\end{array}$ & 40 & 10 & 30 & 10 & 41 & 16 & 25 & 6 \\
\hline Mean & $\begin{array}{l}0.60 \\
(0.13)\end{array}$ & $\begin{array}{l}0.16 \\
(0.80)\end{array}$ & $\begin{array}{l}1.00 * * \\
(0.05)\end{array}$ & $\begin{array}{l}-1.00 \\
(0.65)\end{array}$ & $\begin{array}{l}0.00 \\
(1.00)\end{array}$ & $\begin{array}{l}0.48 \\
(0.49)\end{array}$ & $\begin{array}{l}-0.51 \\
(0.59)\end{array}$ & $\begin{array}{l}0.13 \\
(0.86)\end{array}$ \\
\hline Median & $\begin{array}{l}0.34 \\
(0.15)\end{array}$ & $\begin{array}{l}0.38 \\
(0.81)\end{array}$ & $\begin{array}{l}0.34 * \\
(0.09)\end{array}$ & $\begin{array}{l}-0.04 \\
(0.71)\end{array}$ & $\begin{array}{l}0.11 \\
(0.82)\end{array}$ & $\begin{array}{l}-0.10 \\
(0.60)\end{array}$ & $\begin{array}{l}0.15 \\
(0.81)\end{array}$ & $\begin{array}{l}0.01 \\
(0.59)\end{array}$ \\
\hline $\begin{array}{l}N \\
\text { Total }\end{array}$ & 25 & 12 & 13 & 4 & 25 & 13 & 12 & 3 \\
\hline Mean & $\begin{array}{l}0.33 * * \\
(0.04)\end{array}$ & $\begin{array}{l}0.21 \\
(0.39)\end{array}$ & $\begin{array}{l}0.44 * * \\
(0.04)\end{array}$ & $\begin{array}{l}0.04 \\
(0.94)\end{array}$ & $\begin{array}{l}-0.25 \\
(0.60)\end{array}$ & $\begin{array}{l}0.36 \\
(0.24)\end{array}$ & $\begin{array}{l}-0.87 \\
(0.33)\end{array}$ & $\begin{array}{l}-1.08 \\
(0.13)\end{array}$ \\
\hline Median & $\begin{array}{l}0.25^{* *} \\
(0.04)\end{array}$ & $\begin{array}{l}0.19 \\
(0.38)\end{array}$ & $\begin{array}{l}0.34 * * \\
(0.05)\end{array}$ & $\begin{array}{l}0.40 \\
(0.52)\end{array}$ & $\begin{array}{l}-0.14 \\
(0.92)\end{array}$ & $\begin{array}{l}-0.27 \\
(0.75)\end{array}$ & $\begin{array}{l}-0.11 \\
(0.71)\end{array}$ & $\begin{array}{l}-0.49 \\
(0.16)\end{array}$ \\
\hline$N$ & 107 & 50 & 57 & 19 & 108 & 55 & 53 & 16 \\
\hline
\end{tabular}

This table shows mean and median abnormal returns of pro- and demotions within the DAX family from 2010 to 2019 on the announcement date. Actual changes refer to all actual index changes, correctly predicted changes refer to actual changes that were predicted by the forecasting model described in Sect. 2, not predicted refer to actual changes that were not predicted, and wrongly predicted refers to predicted changes that were not actual changes. The abnormal return is the total return of a stock minus its respective index total return. The numbers in brackets refer to the $p$ value of a two-sided $t$ test for the mean and the Wilcoxon (1945) $p$ value for the median

*Signals significance at the $10 \%$-level, **at the $5 \%$-level, and ***at the $1 \%$-level

The constant and the promotion dummy in Table 6 are statistically significant and have the expected signs, i.e., demotions (promotions) earn a negative (positive) abnormal return. Market capitalization and its interaction terms with the promotion dummy are statistically insignificant but have the expected signs, too. That is, larger stocks tend to have smaller abnormal returns. This could be due to market frictions, such as illiquidity or due to behavioral biases, such as the lack of investor attention (see Barber and Odean (2008) or Da et al. (2011)) as larger stocks are more likely to receive investor's attention. Since Table 6 also shows that a higher
VDAX is related to smaller abnormal returns, funding constraints do not seem to drive the results.

Although the results indicate that abnormal returns are partly driven by size, it does not make them unexploitable for the following reasons. First, although smaller in magnitude, abnormal returns are still present in the larger DAX and MDAX indices. Second, index trackers are likely to already hold demotions before their announcement and buy promotions after their announcement. Since they implement the index changes regardless of stock size, they should consider shifting their trading 
Table 4 Abnormal returns on the AD+1 by category—statistics

\begin{tabular}{|c|c|c|c|c|c|c|c|c|}
\hline & \multicolumn{4}{|l|}{ Promotion } & \multicolumn{4}{|l|}{ Demotion } \\
\hline & Actual changes & $\begin{array}{l}\text { Correctly } \\
\text { predicted }\end{array}$ & Not predicted & $\begin{array}{l}\text { Wrongly pre- } \\
\text { dicted }\end{array}$ & Actual changes & $\begin{array}{l}\text { Correctly pre- } \\
\text { dicted }\end{array}$ & Not predicted & Wrongly predicted \\
\hline \multicolumn{9}{|l|}{$D A X$} \\
\hline Mean & $\begin{array}{l}0.33 \\
(0.53)\end{array}$ & $\begin{array}{l}0.49 \\
(0.51)\end{array}$ & $\begin{array}{l}-0.07 \\
(0.91)\end{array}$ & $\begin{array}{l}1.24 \\
(-)\end{array}$ & $\begin{array}{l}-1.15 \\
(0.29)\end{array}$ & $\begin{array}{l}-1.63 \\
(0.29)\end{array}$ & $\begin{array}{l}0.06 \\
(0.94)\end{array}$ & $\begin{array}{l}0.63 \\
(-)\end{array}$ \\
\hline Median & $\begin{array}{l}0.41 \\
(0.40)\end{array}$ & $\begin{array}{l}0.90 \\
(0.35)\end{array}$ & $\begin{array}{l}-0.07 \\
(0.65)\end{array}$ & $\begin{array}{l}1.24 \\
(0.32)\end{array}$ & $\begin{array}{l}-0.77 \\
(0.31)\end{array}$ & $\begin{array}{l}-0.93 \\
(0.35)\end{array}$ & $\begin{array}{l}0.06 \\
(0.65)\end{array}$ & $\begin{array}{l}0.63 \\
(0.32)\end{array}$ \\
\hline $\begin{array}{l}N \\
M D A X\end{array}$ & 7 & 5 & 2 & 1 & 7 & 5 & 2 & 1 \\
\hline Mean & $\begin{array}{l}0.27 \\
(0.31)\end{array}$ & $\begin{array}{l}0.31 \\
(0.33)\end{array}$ & $\begin{array}{l}0.19 \\
(0.71)\end{array}$ & $\begin{array}{l}-2.17 \\
(0.15)\end{array}$ & $\begin{array}{l}-0.66^{*} \\
(0.08)\end{array}$ & $\begin{array}{l}-0.10 \\
(0.84)\end{array}$ & $\begin{array}{l}-1.50^{* *} \\
(0.01)\end{array}$ & $\begin{array}{l}1.34 \\
(0.34)\end{array}$ \\
\hline Median & $\begin{array}{l}0.36 \\
(0.16)\end{array}$ & $\begin{array}{l}0.36 \\
(0.20)\end{array}$ & $\begin{array}{l}0.58 \\
(0.43)\end{array}$ & $\begin{array}{l}-2.06^{*} \\
(0.07)\end{array}$ & $\begin{array}{l}-0.77 * \\
(0.08)\end{array}$ & $\begin{array}{l}-0.56 \\
(0.85)\end{array}$ & $\begin{array}{l}-0.91^{* * * *} \\
(0.01)\end{array}$ & $\begin{array}{l}0.95 \\
(0.25)\end{array}$ \\
\hline $\begin{array}{l}N \\
S D A X\end{array}$ & 35 & 23 & 12 & 4 & 35 & 21 & 14 & 6 \\
\hline Mean & $\begin{array}{l}1.00 * * \\
(0.02)\end{array}$ & $\begin{array}{l}0.94 \\
(0.14)\end{array}$ & $\begin{array}{l}1.03 * \\
(0.07)\end{array}$ & $\begin{array}{l}0.27 \\
(0.44)\end{array}$ & $\begin{array}{l}-0.87 * \\
(0.06)\end{array}$ & $\begin{array}{l}-0.74 \\
(0.15)\end{array}$ & $\begin{array}{l}-0.95 \\
(0.18)\end{array}$ & $\begin{array}{l}0.52 \\
(0.43)\end{array}$ \\
\hline Median & $\begin{array}{l}0.35^{* * * *} \\
(0.01)\end{array}$ & $\begin{array}{l}1.14 \\
(0.14)\end{array}$ & $\begin{array}{l}0.32 * * \\
(0.04)\end{array}$ & $\begin{array}{l}0.19 \\
(0.39)\end{array}$ & $\begin{array}{l}-0.41^{* *} \\
(0.02)\end{array}$ & $\begin{array}{l}-0.29 \\
(0.15)\end{array}$ & $\begin{array}{l}-0.85^{*} \\
(0.09)\end{array}$ & $\begin{array}{l}0.08 \\
(0.75)\end{array}$ \\
\hline$N$ & 39 & 10 & 29 & 10 & 41 & 16 & 25 & 6 \\
\hline TecDAX & & & & & & & & \\
\hline mean & $\begin{array}{l}1.42 * * \\
(0.02)\end{array}$ & $\begin{array}{l}0.54 \\
(0.39)\end{array}$ & $\begin{array}{l}2.24 * * \\
(0.03)\end{array}$ & $\begin{array}{l}3.68 \\
(0.18)\end{array}$ & $\begin{array}{l}-1.54 * * \\
(0.04)\end{array}$ & $\begin{array}{l}-3.17 * * \\
(0.01)\end{array}$ & $\begin{array}{l}0.22 \\
(0.78)\end{array}$ & $\begin{array}{l}-0.23 \\
(0.38)\end{array}$ \\
\hline median & $\begin{array}{l}1.06^{* * *} \\
(0.03)\end{array}$ & $\begin{array}{l}0.01 \\
(0.53)\end{array}$ & $\begin{array}{l}2.65 * * \\
(0.04)\end{array}$ & $\begin{array}{l}2.08 * \\
(0.07)\end{array}$ & $\begin{array}{l}-0.89 * * \\
(0.04)\end{array}$ & $\begin{array}{l}-1.93^{* *} \\
(0.01)\end{array}$ & $\begin{array}{l}-0.22 \\
(1.00)\end{array}$ & $\begin{array}{l}-0.20 \\
(0.29)\end{array}$ \\
\hline $\begin{array}{l}N \\
\text { Total }\end{array}$ & 25 & 12 & 13 & 4 & 25 & 13 & 12 & 3 \\
\hline Mean & $\begin{array}{l}0.82 * * * \\
(0.00)\end{array}$ & $\begin{array}{l}0.51 * * \\
(0.04)\end{array}$ & $\begin{array}{l}1.09 * * * \\
(0.01)\end{array}$ & $\begin{array}{l}0.52 \\
(0.44)\end{array}$ & $\begin{array}{l}-0.98^{* * * *} \\
(0.00)\end{array}$ & $\begin{array}{l}-1.15^{* * *} \\
(0.00)\end{array}$ & $\begin{array}{l}-0.79 * * \\
(0.05)\end{array}$ & $\begin{array}{l}0.69 \\
(0.20)\end{array}$ \\
\hline Median & $\begin{array}{l}0.50 * * * \\
(0.00)\end{array}$ & $\begin{array}{l}0.50 * * \\
(0.03)\end{array}$ & $\begin{array}{l}0.53 * * * \\
(0.00)\end{array}$ & $\begin{array}{l}0.33 \\
(0.38)\end{array}$ & $\begin{array}{l}-0.73^{* * *} \\
(0.00)\end{array}$ & $\begin{array}{l}-0.77 * * * \\
(0.01)\end{array}$ & $\begin{array}{l}-0.56^{* * * *} \\
(0.00)\end{array}$ & $\begin{array}{l}0.17 \\
(0.20)\end{array}$ \\
\hline$N$ & 106 & 50 & 56 & 19 & 108 & 55 & 53 & 16 \\
\hline
\end{tabular}

This table shows mean and median abnormal returns of pro- and demotions within the DAX family from 2010 to 2019 on the day after the $\mathrm{AD}+1$. Actual changes refer to all actual index changes, correctly predicted changes refer to actual changes that were predicted by the forecasting model described in Sect. 2, not predicted refer to actual changes that were not predicted, and wrongly predicted refers to predicted changes that were not actual changes. The abnormal return is the total return of a stock minus its respective index total return. The numbers in brackets refer to the $p$ value of a two-sided $t$ test for the mean and the Wilcoxon (1945) $p$ value for the median

$*$ Signals significance at the $10 \%$-level, **at the $5 \%$-level, and ***at the $1 \%$-level

partly before the announcement date. Instead, Green and Jame (2011) show that they primarily trade after the announcement to avoid tracking error risk (Blume and Edelen 2004). Therefore, it seems rational for risk-averse index trackers to avoid profitable pre-announcement trading to minimize the tracking error. Nonetheless, in an efficient market, arbitrageurs that are not constrained by tracking error should step in and collect these profitable opportunities.
Finally, I show that my results are also economically meaningful. A trading strategy that could $100 \%$ correctly predict index changes in the DAX family and equally weighting longs (shorts) promotions (demotions) at the closing price on the $\mathrm{AD}$ and closes the position at the closing price on the AD+1 would have yielded a cumulative return of $72.35 \%$ during 2010 to 2019 . Figure 3 shows that the return comes primarily from the long side with very little drawdowns, yielding an annualized 
Table 5 Correctly predicted vs. not predicted changes on the AD+1

\begin{tabular}{|c|c|c|c|c|}
\hline & DAX promotions & DAX demotions & MDAX promotions & MDAX demotions \\
\hline \multirow[t]{2}{*}{ Mean } & 0.56 & -1.69 & 0.12 & $1.41 *$ \\
\hline & $(0.54)$ & $(0.31)$ & $(0.85)$ & $(0.06)$ \\
\hline \multirow[t]{3}{*}{ Median } & 0.97 & -0.99 & -0.22 & 0.35 \\
\hline & $(0.44)$ & $(0.25)$ & $(0.94)$ & $(0.11)$ \\
\hline & SDAX promotions & SDAX demotions & TecDAX promotions & TecDAX demotions \\
\hline \multirow[t]{2}{*}{ Mean } & -0.09 & 0.21 & -1.70 & $-3.38 * *$ \\
\hline & $(0.91)$ & $(0.81)$ & $(0.14)$ & $(0.02)$ \\
\hline \multirow[t]{2}{*}{ Median } & 0.82 & 0.56 & -2.63 & $-1.72 * *$ \\
\hline & $(0.44)$ & $(0.67)$ & $(0.14)$ & $(0.02)$ \\
\hline
\end{tabular}

This table shows mean and median of the difference between abnormal returns of actual changes that were correctly predicted and abnormal returns of actual changes that were not predicted by my model. The changes refer to index changes within the DAX family from 2010 to 2019. The abnormal return is the total return of a stock minus its respective index total return on the AD+1. The numbers in brackets refer to the $p$ value of a Welch (1938) test for the mean and the Mann-Whitney test $p$ value for the median

*Signals significance at the $10 \%$-level, **at the $5 \%$-level, and ***at the $1 \%$-level

Table 6 Cross-sectional regression

\begin{tabular}{llll}
\hline & (I) & (II) & (III) \\
\hline Constant & $-1.02 * * *$ & $-1.00^{* * *}$ & $-1.00^{* * *}$ \\
& $(0.00)$ & $(0.00)$ & $(0.00)$ \\
$\mathrm{D}^{\mathrm{PM}}$ & $1.85^{* * *}$ & $1.87 * * *$ & $1.87 * * *$ \\
& $(0.00)$ & $(0.00)$ & $(0.00)$ \\
Market Cap & & 0.02 & 0.02 \\
& & $(0.86)$ & $(0.84)$ \\
$\mathrm{D}^{\mathrm{PM} * \text { Market Cap }}$ & & -0.06 & -0.03 \\
& & $(0.62)$ & $(0.62)$ \\
VDAX & & & 0.01 \\
& & & $(0.51)$ \\
$\mathrm{D}^{\mathrm{PM}} *$ VDAX & & & -0.03 \\
& & 209 & $(0.62)$ \\
$\mathrm{N}$ & 209 & 0.1 & 209 \\
Adj. $R^{2}$ & 0.106 & & 0.096 \\
\hline
\end{tabular}

This table shows the results of the regression in Eq. 3. The dependent variable is the abnormal return in percent of stock $i$ at the AD+1 $t$ and Market Cap is the unadjusted market capitalization in billion euro. Market Cap and VDAX are centered. Standard errors are clustered by date, and $p$ values are given in brackets.

*Signals significance at the $10 \%$-level, **at the 5\%-level, and ***at the $1 \%$-level

Sharpe ratio of 1.10. Figure 4 shows the performance of the strategy if predictions have not been made with perfect foresight but according to my model, which is free of any backward-looking bias and thus approximates the real world. The strategy would have yielded a yearly arithmetic average return of $5.61 \%$ with a Sharpe ratio of 0.83 . It is important to understand that this return is achieved by being invested only four times a year. If an investor had the opportunity to invest in such a strategy during ever trading day in a year, she would earn a Sharpe ratio of 6.59 .

Table 7 displays the performance of trading on predictions by AD+1. It shows that in March 2014, the strategy made a particularly large gain of $10.71 \%$ by wrongly predicting the promotion of Software AG into the TecDAX and thus buying it and $5.51 \%$ by correctly predicting the demotion of ADVA AG and thus shorting. However, apart from this event, the magnitude of the trade is relatively homogeneous and hence the mean and median by date and overall are relatively similar, i.e., for the long-short strategy $1.73 \%$ and $1.74 \%$ per announcement date.

\section{Conclusion}

I show that index changes are predictable and still deliver sizeable abnormal returns. The abnormal returns for index changes following their announcement are large, not related to funding constraints, and even present in the largest stocks and most recent index changes. Considering that similar announcement effects are also found internationally (see Kappou et al. (2010) or Biktimirov and Xu (2019)), most index methodologies are rule-based, and index 


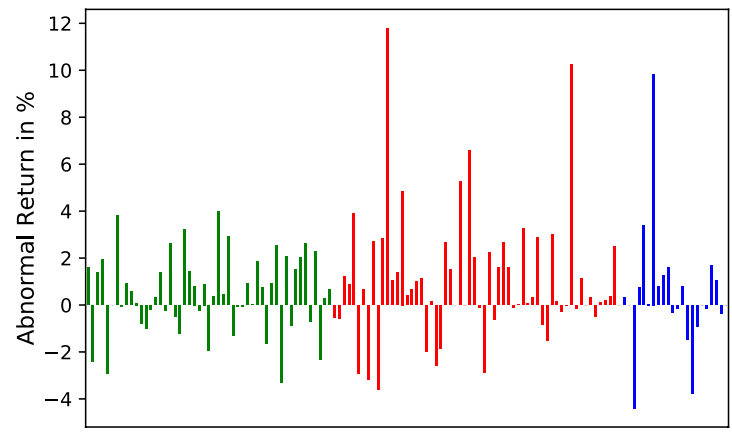

(I) Promotions

Fig. 2 Abnormal returns on the AD+1 by category. This figure shows abnormal returns of promotions and demotions within the DAX Index family from 2010 to 2019 . Green refers to promotions that have been predicted correctly (true positives) by the forecasting model described

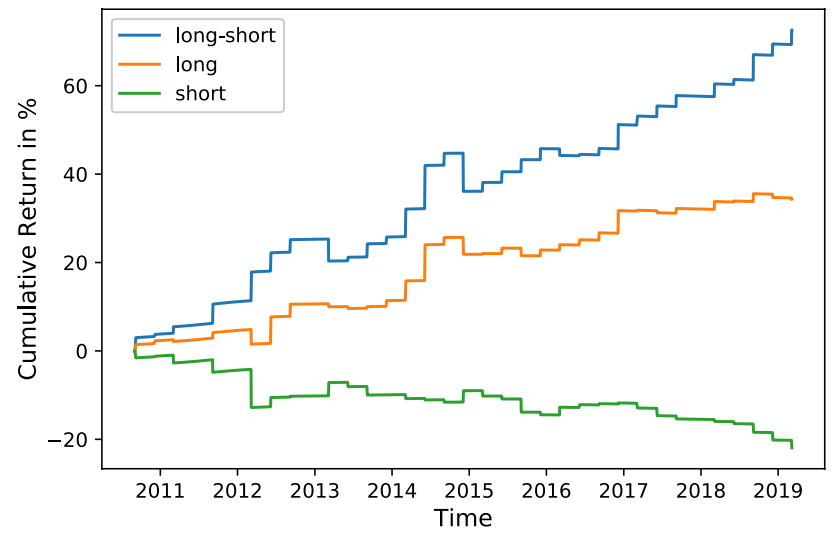

Fig. 3 Cumulative return of actual changes. This table shows the cumulative total return of an investment strategy that longs (shorts) actual DAX, MDAX, SDAX, and TecDax promotions (demotions) on the close of the AD and closes the position at the close of the AD+1. The strategy creates equally weighted portfolios of all the index changes per AD . The sample period is 2010 to 2019

announcements happen on different dates, a strategy that trades on predicted index changes globally is likely to earn high abnormal returns. This supports theories that arbitrageurs might forgo profitable opportunities due to, for example, slow-moving capital restrictions (see Duffie (2010)).

My results also have implications for practitioners. Index funds usually implement index changes after the announcement (Green and Jame 2011) because front-running

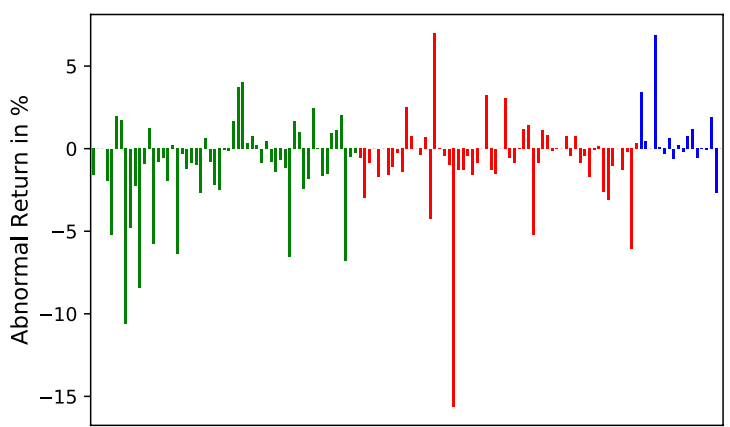

(II) Demotions

in Sect. 2, in red are actual changes that have not been predicted (false negatives) and in blue are changes that have been wrongly predicted to be changes (false positives)

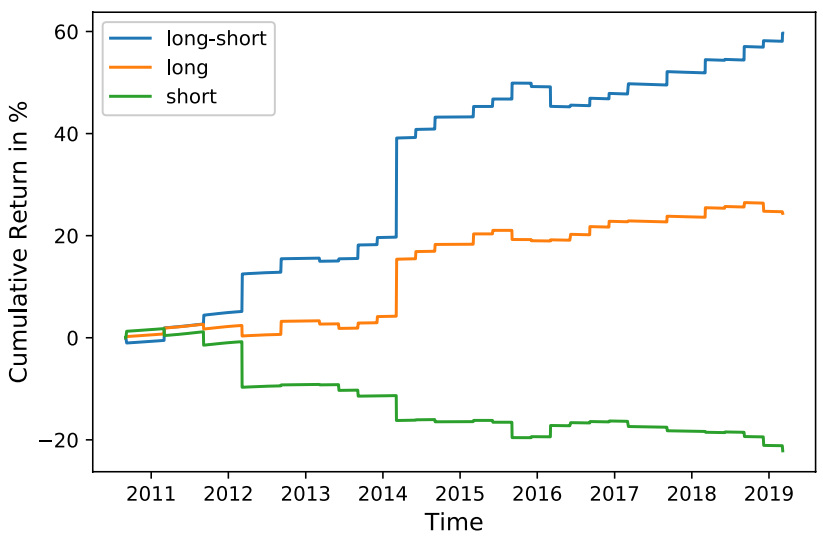

Fig. 4 Cumulative return of predicted changes. This table shows the cumulative total return of an investment strategy that longs (shorts) predicted DAX, MDAX, SDAX, and TecDax promotions (demotions) on the close of the $\mathrm{AD}$ and closes the position at the close of the $\mathrm{AD}+1$. The strategy creates equally weighted portfolios of all the index changes per AD. Predictions are made based on a forecast model described in Sect. 2, and the sample period is 2010 to 2019

announcements expose them to great tracking error risk (Blume and Edelen 2004). However, trading especially smaller changes earlier might protect their shareholders from earning negative abnormal returns in demotions and missing out on positive abnormal returns of promotions, which ultimately resembles a hidden cost for passive investors (Petajisto 2011) and causes underperformance (Gastineau 2004). 
Table 7 Return of predicted changes by announcement date $+1$

\begin{tabular}{|c|c|c|c|c|c|c|}
\hline \multirow[t]{2}{*}{$\mathrm{AD}+1$} & \multicolumn{3}{|l|}{ Mean } & \multicolumn{3}{|l|}{ Median } \\
\hline & Promotions & Demotions & Long-short & Promotions & Demotions & Long-short \\
\hline 2010-09-06 & 0.23 & 1.26 & -1.04 & 1.01 & 1.26 & -0.25 \\
\hline 2011-03-04 & 1.13 & -1.34 & 2.47 & 1.13 & -1.34 & 2.47 \\
\hline 2011-09-06 & -0.92 & -2.60 & 1.68 & 0.06 & -2.75 & 2.81 \\
\hline 2012-03-06 & -2.02 & -9.00 & 6.99 & -2.02 & -9.00 & 6.99 \\
\hline 2012-09-06 & 2.55 & 0.21 & 2.34 & 2.65 & 1.97 & 0.68 \\
\hline 2013-03-07 & -0.63 & -0.10 & -0.53 & -0.63 & -0.10 & -0.53 \\
\hline 2013-06-06 & -0.87 & -1.24 & 0.37 & -0.87 & -1.24 & 0.37 \\
\hline 2013-09-05 & 0.98 & -1.31 & 2.29 & 0.98 & -1.31 & 2.29 \\
\hline 2013-12-05 & 1.17 & 0.00 & 1.17 & 1.17 & 0.00 & 1.17 \\
\hline 2014-03-06 & 10.71 & -5.51 & 16.22 & 10.71 & -5.51 & 16.22 \\
\hline 2014-06-05 & 1.22 & 0.08 & 1.13 & 1.22 & 0.08 & 1.13 \\
\hline 2014-09-04 & 1.14 & -0.51 & 1.66 & 0.37 & -0.52 & 0.88 \\
\hline 2015-03-05 & 1.71 & 0.29 & 1.42 & 2.24 & 0.58 & 1.66 \\
\hline 2015-06-04 & 0.58 & -0.43 & 1.00 & 0.58 & -0.43 & 1.00 \\
\hline 2015-09-04 & -1.48 & -3.61 & 2.13 & -1.38 & -3.98 & 2.60 \\
\hline $2015-12-04$ & -0.19 & 0.25 & -0.44 & 0.02 & -0.11 & 0.13 \\
\hline 2016-03-04 & 0.19 & 2.75 & -2.57 & -0.11 & 2.41 & -2.53 \\
\hline 2016-06-06 & 0.97 & 0.74 & 0.23 & 0.97 & 0.74 & 0.23 \\
\hline 2016-09-06 & 1.33 & 0.33 & 1.00 & 1.33 & 0.33 & 1.00 \\
\hline 2016-12-06 & 0.94 & 0.21 & 0.72 & 0.94 & 0.21 & 0.72 \\
\hline 2017-03-06 & 0.14 & -1.22 & 1.36 & 0.14 & -1.22 & 1.36 \\
\hline 2017-09-06 & 0.91 & -0.84 & 1.75 & 0.91 & -0.84 & 1.75 \\
\hline 2018-03-06 & 1.51 & -0.20 & 1.71 & 1.73 & 0.46 & 1.26 \\
\hline 2018-06-06 & 0.27 & 0.16 & 0.12 & 0.72 & 0.13 & 0.60 \\
\hline 2018-09-06 & 0.69 & -1.03 & 1.72 & 1.32 & -0.44 & 1.76 \\
\hline 2018-12-06 & -1.26 & -2.07 & 0.81 & -1.26 & -2.07 & 0.81 \\
\hline 2019-03-06 & -0.26 & -1.27 & 1.01 & -0.28 & -0.70 & 0.42 \\
\hline Total Mean & 0.77 & -0.96 & 1.73 & 0.88 & -0.87 & 1.74 \\
\hline Total Median & 0.73 & -0.47 & 1.27 & 0.89 & -0.43 & 1.07 \\
\hline
\end{tabular}

This table shows the mean and median total returns of an investment strategy that longs (shorts) predicted DAX, MDAX, SDAX, and TecDax promotions (demotions) on the close of the AD and closes the position at the close of the AD+1. Predictions are made based on a forecast model described in Sect. 2
Acknowledgments Open Access funding provided by Projekt DEAL.

Open Access This article is licensed under a Creative Commons Attribution 4.0 International License, which permits use, sharing, adaptation, distribution and reproduction in any medium or format, as long as you give appropriate credit to the original author(s) and the source, provide a link to the Creative Commons licence, and indicate if changes were made. The images or other third party material in this article are included in the article's Creative Commons licence, unless indicated otherwise in a credit line to the material. If material is not included in the article's Creative Commons licence and your intended use is not permitted by statutory regulation or exceeds the permitted use, you will need to obtain permission directly from the copyright holder. To view a copy of this licence, visit http://creativecommons.org/licenses/by/4.0/.

\section{Appendix}

See Tables 8, 9, 10, 11, 12, and 13 
Table 8 Changes by Date (I)

\begin{tabular}{|c|c|c|c|c|}
\hline Announcement date & Index & Stock & ISIN & Result \\
\hline 2018-09-05 & DAX & WIRECARD AG & DE0007472060 & Correctly predicted \\
\hline 2018-09-05 & DAX & COMMERZBANK AG KONV. & DE000CBK1001 & Correctly predicted \\
\hline 2018-03-05 & DAX & COVESTRO AG O.N. & DE0006062144 & Correctly predicted \\
\hline 2018-03-05 & DAX & PROSIEBENSAT.1 NA O.N. & DE000PSM7770 & Correctly predicted \\
\hline 2016-03-03 & DAX & PROSIEBENSAT.1 NA O.N. & DE000PSM7770 & Correctly predicted \\
\hline 2016-03-03 & DAX & K+S AG NA O.N. & DE000KSAG888 & Correctly predicted \\
\hline 2015-09-03 & DAX & DT.ANNINGTON IMM.SE & DE000A1ML7J1 & Correctly predicted \\
\hline 2015-09-03 & DAX & LANXESS AG & DE0005470405 & Correctly predicted \\
\hline 2015-03-04 & DAX & PROSIEBENSAT.1 NA O.N. & DE000PSM7770 & Wrongly predicted \\
\hline 2015-03-04 & DAX & LANXESS AG & DE0005470405 & Wrongly predicted \\
\hline 2012-09-05 & DAX & CONTINENTAL AG O.N. & DE0005439004 & Correctly predicted \\
\hline 2012-09-05 & DAX & LANXESS AG & DE0005470405 & Not predicted \\
\hline 2012-09-05 & DAX & MAN SE ST O.N. & DE0005937007 & Correctly predicted \\
\hline 2012-09-05 & DAX & METRO AG ST O.N. & DE0007257503 & Not predicted \\
\hline 2010-06-04 & DAX & HEIDELBERGCEMENT AG O.N. & DE0006047004 & Not predicted \\
\hline 2010-06-04 & DAX & SALZGITTER AG O.N. & DE0006202005 & Not predicted \\
\hline 2019-03-05 & MDAX & KNORR-BREMSE AG INH O.N. & DE000KBX1006 & Correctly predicted \\
\hline 2019-03-05 & MDAX & DIALOG SEMICOND. LS-,10 & GB0059822006 & Correctly predicted \\
\hline 2019-03-05 & MDAX & GRENKE AG NA O.N. & DE000A161N30 & Wrongly predicted \\
\hline 2019-03-05 & MDAX & SALZGITTER AG O.N. & DE0006202005 & Correctly predicted \\
\hline 2019-03-05 & MDAX & SCHAEFFLER AG INH. VZO & DE000SHA0159 & Not predicted \\
\hline 2019-03-05 & MDAX & WACKER CHEMIE O.N. & DE000WCH8881 & Wrongly predicted \\
\hline 2019-03-05 & MDAX & NORMA GROUP SE NA O.N. & DE000A1H8BV3 & Wrongly predicted \\
\hline $2018-12-05$ & MDAX & CARL-ZEISS MEDITEC AG & DE0005313704 & Correctly predicted \\
\hline 2018-12-05 & MDAX & CTS EVENTIM AG & DE0005470306 & Correctly predicted \\
\hline 2018-09-05 & MDAX & ALSTRIA OFFICE REIT-AG & DE000A0LD2U1 & Wrongly predicted \\
\hline 2018-09-05 & MDAX & CECONOMY AG ST O.N. & DE0007257503 & Wrongly predicted \\
\hline 2018-06-05 & MDAX & PUMA AG & DE0006969603 & Correctly predicted \\
\hline 2018-06-05 & MDAX & DELIVERY HERO AG NA O.N. & DE000A2E4K43 & Correctly predicted \\
\hline 2018-06-05 & MDAX & SCOUT24 AG NA & DE000A12DM80 & Correctly predicted \\
\hline 2018-06-05 & MDAX & ALSTRIA OFFICE REIT AG & DE000A0LD2U1 & Correctly predicted \\
\hline 2018-06-05 & MDAX & KRONES AG O.N. & DE0006335003 & Correctly predicted \\
\hline 2018-06-05 & MDAX & STADA ARZNEIMITT.VNA O.N. & DE0007251803 & Not predicted \\
\hline 2018-06-05 & MDAX & CECONOMY AG ST O.N. & DE0007257503 & Wrongly predicted \\
\hline 2018-03-05 & MDAX & ROCKET INTERNET SE & DE000A12UKK6 & Correctly predicted \\
\hline 2018-03-05 & MDAX & AROUNDTOWN EO-,01 & LU1673108939 & Correctly predicted \\
\hline 2018-03-05 & MDAX & SUEDZUCKER MA./OCHS. O.N. & DE0007297004 & Correctly predicted \\
\hline 2018-03-05 & MDAX & STEINHOFF INT.HLDG.EO-,50 & NL0011375019 & Correctly predicted \\
\hline 2017-09-05 & MDAX & GRAND CITY PROPERT.EO-,10 & LU0775917882 & Correctly predicted \\
\hline 2017-09-05 & MDAX & METRO WHOLE.FOOD ST O.N. & DE000BFB0019 & Not predicted \\
\hline 2017-09-05 & MDAX & BILFINGER BERGER AG & DE0005909006 & Correctly predicted \\
\hline 2017-09-05 & MDAX & RATIONAL AG & DE0007010803 & Not predicted \\
\hline 2016-12-05 & MDAX & UNIPER SE NA. & DE000UNSE018 & Correctly predicted \\
\hline 2016-12-05 & MDAX & INNOGY SE INH. O.N. & DE000A2AADD2 & Not predicted \\
\hline 2016-12-05 & MDAX & GILDEMEISTER AG O.N. & DE0005878003 & Correctly predicted \\
\hline 2016-12-05 & MDAX & RHOEN-KLINIKUM O.N. & DE0007042301 & Not predicted \\
\hline 2016-06-03 & MDAX & SCHAEFFLER AG INH. VZO & DE000SHA0159 & Correctly predicted \\
\hline 2016-06-03 & MDAX & WINCOR NIXDORF O.N. & DE000A0CAYB2 & Correctly predicted \\
\hline 2016-03-03 & MDAX & ALSTRIA OFFICE REIT AG & DE000A0LD2U1 & Correctly predicted \\
\hline 2016-03-03 & MDAX & STEINHOFF INT.HLDG.EO-,50 & NL0011375019 & Not predicted \\
\hline 2016-03-03 & MDAX & SCHAEFFLER AG INH. VZO & DE000SHA0159 & Wrongly predicted \\
\hline 2016-03-03 & MDAX & ELRINGKLINGER AG NA O.N. & DE0007856023 & Correctly predicted \\
\hline 2016-03-03 & MDAX & KLOECKNER + CO SE NA & DE000KC01000 & Correctly predicted \\
\hline
\end{tabular}

This table shows actual and predicted pro- and demotions within the DAX family. Correctly predicted changes refer to actual changes that were predicted by the forecasting model described in Sect. 2, not predicted refer to actual changes that were not predicted, and wrongly predicted refers to predicted changes that were not actual changes 
Table 9 Changes by Date (II)

\begin{tabular}{|c|c|c|c|c|}
\hline Announcement date & Index & Stock & ISIN & Result \\
\hline 2015-12-03 & MDAX & STROEER OUT-OF-H.AG & DE0007493991 & Correctly predicted \\
\hline $2015-12-03$ & MDAX & COVESTRO AG O.N. & DE0006062144 & Not predicted \\
\hline $2015-12-03$ & MDAX & KABEL DT. HOLDING AG O.N. & DE000KD88880 & Not predicted \\
\hline 2015-12-03 & MDAX & MAN SE ST O.N. & DE0005937007 & Not predicted \\
\hline $2015-12-03$ & MDAX & ELRINGKLINGER AG NA O.N. & DE0007856023 & Wrongly predicted \\
\hline 2015-09-03 & MDAX & HELLA KGAA HUECK+CO. O.N. & DE000A13SX22 & Correctly predicted \\
\hline 2015-09-03 & MDAX & DT.PFANDBRIEFBK AG & DE0008019001 & Not predicted \\
\hline 2015-09-03 & MDAX & GERRY WEBER INTERNAT.O.N. & DE0003304101 & Correctly predicted \\
\hline 2015-09-03 & MDAX & CELESIO AG NAM. O.N. & DE000CLS1001 & Not predicted \\
\hline 2015-06-03 & MDAX & ZALANDO SE & DE000ZAL1111 & Not predicted \\
\hline $2015-06-03$ & MDAX & BERTRANDT AG O.N. & DE0005232805 & Not predicted \\
\hline 2014-09-03 & MDAX & DT.ANNINGTON IMM.SE & DE000A1ML7J1 & Correctly predicted \\
\hline 2014-09-03 & MDAX & KION GROUP AG & DE000KGX8881 & Not predicted \\
\hline 2014-09-03 & MDAX & RATIONAL AG & DE0007010803 & Correctly predicted \\
\hline 2014-09-03 & MDAX & SGL CARBON SE O.N. & DE0007235301 & Not predicted \\
\hline 2013-09-04 & MDAX & EVONIK INDUSTRIES AG & DE000EVNK013 & Correctly predicted \\
\hline 2013-09-04 & MDAX & OSRAM LICHT AG NA O.N. & DE000LED4000 & Not predicted \\
\hline 2013-09-04 & MDAX & RTL GROUP & LU0061462528 & Not predicted \\
\hline 2013-09-04 & MDAX & BAYWA AG VINK.NA. O.N. & DE0005194062 & Correctly predicted \\
\hline 2013-09-04 & MDAX & PUMA AG & DE0006969603 & Not predicted \\
\hline 2013-09-04 & MDAX & SGL CARBON SE O.N. & DE0007235301 & Not predicted \\
\hline 2013-06-05 & MDAX & LEG IMMOBILIEN AG & DE000LEG1110 & Correctly predicted \\
\hline 2013-06-05 & MDAX & HAMBURG.HAFEN U.LOG.A-SP & DE000A0S8488 & Correctly predicted \\
\hline 2013-03-06 & MDAX & NORMA GROUP AG NA O.N. & DE000A1H8BV3 & Correctly predicted \\
\hline 2013-03-06 & MDAX & VOSSLOH AG O.N. & DE0007667107 & Correctly predicted \\
\hline 2012-09-05 & MDAX & TAG IMMOBILIEN AG & DE0008303504 & Correctly predicted \\
\hline 2012-09-05 & MDAX & DEUTZ AG O.N. & DE0006305006 & Correctly predicted \\
\hline 2012-03-05 & MDAX & DUERR AG O.N. & DE0005565204 & Correctly predicted \\
\hline 2012-03-05 & MDAX & HEIDELBERG.DRUCKMA.O.N. & DE0007314007 & Correctly predicted \\
\hline 2011-09-05 & MDAX & GSW IMMOBILIEN AG & DE000GSW1111 & Correctly predicted \\
\hline 2011-09-05 & MDAX & KUKA AG & DE0006204407 & Correctly predicted \\
\hline 2011-09-05 & MDAX & DEUTZ AG O.N. & DE0006305006 & Not predicted \\
\hline 2011-09-05 & MDAX & ALSTRIA OFFICE REIT AG & DE000A0LD2U1 & Wrongly predicted \\
\hline 2011-09-05 & MDAX & PRAKTIKER BAU-U.H.HLDG ON & DE000A0F6MD5 & Correctly predicted \\
\hline 2011-09-05 & MDAX & DEMAG CRANES AG & DE000DCAG010 & Correctly predicted \\
\hline 2011-09-05 & MDAX & IVG IMMOBILIEN AG O.N. & DE0006205701 & Not predicted \\
\hline 2011-09-05 & MDAX & GAGFAH S.A. NOM. EO 1,25 & LU0269583422 & Wrongly predicted \\
\hline 2010-09-03 & MDAX & A.SPRINGER AG VNA & DE0005501357 & Correctly predicted \\
\hline 2010-09-03 & MDAX & BAUER AG & DE0005168108 & Correctly predicted \\
\hline 2010-06-04 & MDAX & BRENNTAG AG & DE000A1DAHH0 & Not predicted \\
\hline 2010-06-04 & MDAX & KABEL DT. HOLDING AG O.N. & DE000KD88880 & Not predicted \\
\hline 2010-06-04 & MDAX & PFLEIDERER AG & DE0006764749 & Not predicted \\
\hline 2010-06-04 & MDAX & MLP AG & DE0006569908 & Not predicted \\
\hline 2019-03-05 & SDAX & AMADEUS FIRE AG & DE0005093108 & Correctly predicted \\
\hline 2019-03-05 & SDAX & ADVA AG OPT.NETW.O.N. & DE0005103006 & Correctly predicted \\
\hline 2019-03-05 & SDAX & VARTA AG O.N. & DE000A0TGJ55 & Correctly predicted \\
\hline 2019-03-05 & SDAX & BAYWA AG NA. & DE0005194005 & Not predicted \\
\hline 2019-03-05 & SDAX & MEDIGENE AG NA O.N. & DE000A1X3W00 & Correctly predicted \\
\hline 2019-03-05 & SDAX & TELE COLUMBUS AG & DE000TCAG172 & Correctly predicted \\
\hline 2019-03-05 & SDAX & GILDEMEISTER AG O.N. & DE0005878003 & Correctly predicted \\
\hline 2019-03-05 & SDAX & VTG AG O.N. & DE000VTG9999 & Not predicted \\
\hline
\end{tabular}

This table shows actual and predicted pro- and demotions within the DAX family. Correctly predicted changes refer to actual changes that were predicted by the forecasting model described in Sect. 2, not predicted refer to actual changes that were not predicted, and wrongly predicted refers to predicted changes that were not actual changes 
Table 10 Changes by Date (III)

\begin{tabular}{|c|c|c|c|c|}
\hline Announcement date & Index & Stock & ISIN & Result \\
\hline 2018-12-05 & SDAX & KNORR-BREMSE AG INH O.N. & DE000KBX1006 & Not predicted \\
\hline 2018-12-05 & SDAX & ADVA OPT.NETW.SE O.N. & DE0005103006 & Wrongly predicted \\
\hline 2018-12-05 & SDAX & BAYWA AG VINK.NA. O.N. & DE0005194062 & Correctly predicted \\
\hline 2018-09-05 & SDAX & BEFESA S.A.ORD.REG. EO 1 & LU1704650164 & Wrongly predicted \\
\hline 2018-09-05 & SDAX & ELRINGKLINGER AG NA O.N. & DE0007856023 & Wrongly predicted \\
\hline 2018-06-05 & SDAX & DWS GROUP GMBH+CO.KGAA ON & DE000DWS1007 & Not predicted \\
\hline 2018-06-05 & SDAX & HELLOFRESH SE INH O.N. & DE000A161408 & Not predicted \\
\hline 2018-06-05 & SDAX & AUMANN AG & DE000A2DAM03 & Not predicted \\
\hline 2018-06-05 & SDAX & DIEBOLD INC. DL 1,25 & US2536511031 & Not predicted \\
\hline 2018-06-05 & SDAX & BET-AT-HOME.COM AG O.N. & DE000A0DNAY5 & Not predicted \\
\hline 2018-03-05 & SDAX & CORESTATE CAPITAL HLDG & LU1296758029 & Correctly predicted \\
\hline 2018-03-05 & SDAX & JOST WERKE AG INH. O.N. & DE000JST4000 & Not predicted \\
\hline 2018-03-05 & SDAX & GERRY WEBER INTERNAT.O.N. & DE0003304101 & Correctly predicted \\
\hline 2018-03-05 & SDAX & MLP AG & DE0006569908 & Not predicted \\
\hline 2017-09-05 & SDAX & AROUNDTOWN EO-,01 & LU1673108939 & Not predicted \\
\hline 2017-09-05 & SDAX & DELIVERY HERO AG NA O.N. & DE000A2E4K43 & Not predicted \\
\hline 2017-09-05 & SDAX & AROUNDTOWN PROP.HD.EO-,01 & CY0105562116 & Wrongly predicted \\
\hline 2017-09-05 & SDAX & AMADEUS FIRE AG & DE0005093108 & Correctly predicted \\
\hline 2017-09-05 & SDAX & WCM BET.GRD.AG O.N. & DE000A1X3X33 & Not predicted \\
\hline 2017-09-05 & SDAX & BAYWA AG NA. & DE0005194005 & Not predicted \\
\hline 2017-06-06 & SDAX & GRAND CITY PROPERT.EO-,10 & LU0775917882 & Not predicted \\
\hline 2017-06-06 & SDAX & TIPP24 SE EO 1 & GB00BHD66J44 & Not predicted \\
\hline 2016-12-05 & SDAX & LEIFHEIT AG O.N. & DE0006464506 & Not predicted \\
\hline 2016-12-05 & SDAX & FERRATUM FINLAND OY & FI4000106299 & Not predicted \\
\hline 2016-09-05 & SDAX & LEIFHEIT AG O.N. & DE0006464506 & Correctly predicted \\
\hline 2016-09-05 & SDAX & COMDIRECT BANK AG & DE0005428007 & Correctly predicted \\
\hline 2016-03-03 & SDAX & WUESTENROT+WUERTT.AG O.N. & DE0008051004 & Not predicted \\
\hline 2016-03-03 & SDAX & HAPAG-LLOYD NA. O.N. & DE000HLAG475 & Not predicted \\
\hline 2016-03-03 & SDAX & WASHTEC AG O.N. & DE0007507501 & Not predicted \\
\hline 2016-03-03 & SDAX & MLP AG & DE0006569908 & Correctly predicted \\
\hline 2016-03-03 & SDAX & SIXT AG VZO O.N. & DE0007231334 & Not predicted \\
\hline 2016-03-03 & SDAX & HORNBACH HOLD.ST O.N. & DE0006083405 & Not predicted \\
\hline 2016-03-03 & SDAX & SCHALTBAU HOLDING O.N & DE0007170300 & Not predicted \\
\hline $2015-12-03$ & SDAX & WCM BET.GRD.AG O.N. & DE000A $1 X 3 X 33$ & Correctly predicted \\
\hline 2015-12-03 & SDAX & SCOUT24 AG NA & DE000A12DM80 & Not predicted \\
\hline $2015-12-03$ & SDAX & SCHAEFFLER AG INH. VZO & DE000SHA0159 & Not predicted \\
\hline 2015-12-03 & SDAX & HYPOPORT AG & DE0005493365 & Not predicted \\
\hline $2015-12-03$ & SDAX & WASHTEC AG O.N. & DE0007507501 & Wrongly predicted \\
\hline 2015-12-03 & SDAX & GESCO AG NA O.N. & DE000A1K0201 & Correctly predicted \\
\hline 2015-12-03 & SDAX & TOM TAILOR HOLDG.AG & DE000A0STST2 & Correctly predicted \\
\hline 2015-12-03 & SDAX & SHW AG & DE000A1JBPV9 & Not predicted \\
\hline 2015-09-03 & SDAX & SIXT AG VZO O.N. & DE0007231334 & Not predicted \\
\hline 2015-09-03 & SDAX & SIXT LEASING O.N. & DE000A0DPRE6 & Wrongly predicted \\
\hline
\end{tabular}


Table 10 (continued)

\begin{tabular}{lllll}
\hline Announcement date & Index & Stock & ISIN & Result \\
\hline $2015-09-03$ & SDAX & VILLEROY + BOCH AG VZ & DE0007657231 & Correctly predicted \\
$2015-06-03$ & SDAX & TELE COLUMBUS AG & DE000TCAG172 & Correctly predicted \\
$2015-06-03$ & SDAX & ADLER REAL ESTATE AG & DE0005008007 & Not predicted \\
$2015-06-03$ & SDAX & KOENIG + BAUER AG ST O.N. & DE0007193500 & Not predicted \\
$2015-06-03$ & SDAX & LEIFHEIT AG O.N. & DE0006464506 & Wrongly predicted \\
$2015-06-03$ & SDAX & SURTECO SE & DE0005176903 & Correctly predicted \\
$2015-06-03$ & SDAX & DELTICOM AG & DE0005146807 & Not predicted \\
$2015-06-03$ & SDAX & BAUER AG & DE0005168108 & Not predicted \\
$2015-06-03$ & SDAX & DO DT.OFFICE AG O.N. & DE000PRME020 & Wrongly predicted \\
$2015-03-04$ & SDAX & WESTGRUND AG & DE000A0HN4T3 & Wrongly predicted \\
$2015-03-04$ & SDAX & SURTECO SE & Wrongly predicted \\
\hline
\end{tabular}

This table shows actual and predicted pro- and demotions within the DAX family. Correctly predicted changes refer to actual changes that were predicted by the forecasting model described in Sect. 2, not predicted refer to actual changes that were not predicted, and wrongly predicted refers to predicted changes that were not actual changes 
Table 11 Changes by Date (IV)

\begin{tabular}{|c|c|c|c|c|}
\hline Announcement date & Index & Stock & ISIN & Result \\
\hline 2014-12-03 & SDAX & ZALANDO SE & DE000ZAL1111 & Not predicted \\
\hline 2014-12-03 & SDAX & CENTROTEC SUSTAINABLE O.N & DE0005407506 & Not predicted \\
\hline 2014-09-03 & SDAX & STABILUS S.A. INH. EO-,01 & LU1066226637 & Correctly predicted \\
\hline 2014-09-03 & SDAX & BRAAS MONIER BD.GR.EO-,01 & LU1075065190 & Not predicted \\
\hline 2014-09-03 & SDAX & HAWESKO HOLDING AG SVG & DE0006042708 & Correctly predicted \\
\hline 2014-09-03 & SDAX & BALDA AG O.N. & DE0005215107 & Not predicted \\
\hline 2014-06-04 & SDAX & HORNBACH HOLD.VZO O.N. & DE0006083439 & Not predicted \\
\hline 2014-06-04 & SDAX & BORUSSIA DORTMUND & DE0005493092 & Not predicted \\
\hline 2014-06-04 & SDAX & VTG AG O.N. & DE000VTG9999 & Wrongly predicted \\
\hline 2014-06-04 & SDAX & KOENIG + BAUER AG ST O.N. & DE0007193500 & Correctly predicted \\
\hline 2014-06-04 & SDAX & AIR BERLIN PLC EO -,25 & GB00B $128 \mathrm{C} 026$ & Not predicted \\
\hline 2014-03-05 & SDAX & SURTECO SE & DE0005176903 & Not predicted \\
\hline 2014-03-05 & SDAX & CAPITAL STAGE AG & DE0006095003 & Not predicted \\
\hline 2014-03-05 & SDAX & $\mathrm{H}+\mathrm{R}$ WASAG AG & DE0007757007 & Not predicted \\
\hline 2014-03-05 & SDAX & VTG AG O.N. & DE000VTG9999 & Not predicted \\
\hline 2013-12-04 & SDAX & SHW AG & DE000A1JBPV9 & Correctly predicted \\
\hline 2013-12-04 & SDAX & MVV ENERGIE AG O.N. & DE000A0H52F5 & Correctly predicted \\
\hline 2013-09-04 & SDAX & KION GROUP AG & DE000KGX8881 & Not predicted \\
\hline 2013-09-04 & SDAX & DT.ANNINGTON IMM.SE & DE000A1ML7J1 & Not predicted \\
\hline 2013-09-04 & SDAX & PRAKTIKER BAU-U.H.HLDG ON & DE000A0F6MD5 & Not predicted \\
\hline 2013-09-04 & SDAX & HIGHLIGHT CMNCTS INH.SF 1 & CH0006539198 & Not predicted \\
\hline 2013-09-04 & SDAX & SMT SCHARF AG & DE0005751986 & Not predicted \\
\hline 2013-09-04 & SDAX & R. STAHL AG NA O.N. & DE000A1PHBB5 & Not predicted \\
\hline 2013-06-05 & SDAX & RTL GROUP & LU0061462528 & Not predicted \\
\hline 2013-06-05 & SDAX & R. STAHL AG NA O.N. & DE000A1PHBB5 & Wrongly predicted \\
\hline 2013-06-05 & SDAX & CONSTANTIN MEDIEN AG O.N. & DE0009147207 & Not predicted \\
\hline 2013-06-05 & SDAX & IVG IMMOBILIEN AG O.N. & DE0006205701 & Wrongly predicted \\
\hline 2011-09-05 & SDAX & SCHALTBAU HOLDING O.N & DE0007170300 & Correctly predicted \\
\hline 2011-09-05 & SDAX & DERBY CYCLE AG O.N. & DE000A1H6HN1 & Not predicted \\
\hline 2011-09-05 & SDAX & PRIME OFFICE REIT-AG O.N. & DE000PRME012 & Not predicted \\
\hline 2011-09-05 & SDAX & ELEXIS AG O.N. & DE0005085005 & Correctly predicted \\
\hline 2011-09-05 & SDAX & MEDION AG O.N. & DE0006605009 & Not predicted \\
\hline 2011-03-03 & SDAX & HAMBORNER REIT AG O.N. & DE0006013006 & Correctly predicted \\
\hline 2011-03-03 & SDAX & PFLEIDERER AG & DE0006764749 & Not predicted \\
\hline 2011-03-03 & SDAX & COLON.REAL ESTATE AG & DE0006338007 & Wrongly predicted \\
\hline 2010-12-03 & SDAX & SAF HOLLAND S.A. EO-,01 & LU0307018795 & Not predicted \\
\hline 2010-12-03 & SDAX & HAWESKO HOLDING AG SVG & DE0006042708 & Not predicted \\
\hline 2010-12-03 & SDAX & TELEPLAN INT. NV EO-25 & NL0000229458 & Not predicted \\
\hline 2010-09-03 & SDAX & STROEER OUT-OF-H.AG & DE0007493991 & Not predicted \\
\hline 2010-09-03 & SDAX & SAF HOLLAND S.A. EO-,01 & LU0307018795 & Wrongly predicted \\
\hline 2010-09-03 & SDAX & LOEWE AG O.N. & DE0006494107 & Correctly predicted \\
\hline 2010-09-03 & SDAX & LOEWE AG O.N. & DE000A1X3W34 & Wrongly predicted \\
\hline 2010-06-04 & SDAX & TOM TAILOR HOLDG.AG & DE000A0STST2 & Not predicted \\
\hline 2010-06-04 & SDAX & DYCKERHOFF ST O.N. & DE0005591002 & Not predicted \\
\hline 2010-06-04 & SDAX & VILLEROY + BOCH AG VZ & DE0007657231 & Not predicted \\
\hline 2010-06-04 & SDAX & VBH HOLDING AG O.N. & DE0007600702 & Not predicted \\
\hline 2010-06-04 & SDAX & ZOOPLUS AG & DE0005111702 & Wrongly predicted \\
\hline 2010-06-04 & SDAX & COLON.REAL ESTATE AG & DE0006338007 & Wrongly predicted \\
\hline
\end{tabular}

This table shows actual and predicted pro- and demotions within the DAX family. Correctly predicted changes refer to actual changes that were predicted by the forecasting model described in Sect. 2, not predicted refer to actual changes that were not predicted, and wrongly predicted refers to predicted changes that were not actual changes 
Table 12 Changes by Date (V)

\begin{tabular}{|c|c|c|c|c|}
\hline Announcement date & Index & Stock & ISIN & Result \\
\hline 2018-06-05 & TECDAX & SIEMENS HEALTH.AG NA O.N. & DE000SHL1006 & Correctly predicted \\
\hline 2018-06-05 & TECDAX & MEDIGENE AG NA O.N. & DE000A1X3W00 & Wrongly predicted \\
\hline 2018-03-05 & TECDAX & ISRA VISION O.N. & DE0005488100 & Correctly predicted \\
\hline 2018-03-05 & TECDAX & AUMANN AG & DE000A2DAM03 & Correctly predicted \\
\hline 2018-03-05 & TECDAX & ADVA AG OPT.NETW.O.N. & DE0005103006 & Correctly predicted \\
\hline 2018-03-05 & TECDAX & GFT TECHNOLOGIES AG & DE0005800601 & Correctly predicted \\
\hline 2017-03-03 & TECDAX & AIXTRON AG NA O.N. & DE000A0WMPJ6 & Correctly predicted \\
\hline 2017-03-03 & TECDAX & STRATEC BIOMEDICAL NAM.ON & DE000STRA555 & Correctly predicted \\
\hline 2016-12-05 & TECDAX & MEDIGENE AG NA O.N. & DE000A1X3W00 & Not predicted \\
\hline 2016-12-05 & TECDAX & AIXTRON AG NA O.N. & DE000A0WMPJ6 & Not predicted \\
\hline 2016-09-05 & TECDAX & QUANMAX AG (Z.REG.MKT.Z.) & AT0000A0E9W5 & Correctly predicted \\
\hline 2016-09-05 & TECDAX & SUESS MICROTEC NA O.N. & DE000A1K0235 & Correctly predicted \\
\hline 2016-03-03 & TECDAX & SLM SOLUTIONS GRP AG & DE000A111338 & Correctly predicted \\
\hline 2016-03-03 & TECDAX & SUESS MICROTEC NA O.N. & DE000A1K0235 & Not predicted \\
\hline 2016-03-03 & TECDAX & QSC AG NA O.N. & DE0005137004 & Correctly predicted \\
\hline 2016-03-03 & TECDAX & LPKF LASER+ELECTRON. & DE0006450000 & Not predicted \\
\hline 2015-12-03 & TECDAX & SILTRONIC AG NA O.N. & DE000WAF3001 & Not predicted \\
\hline 2015-12-03 & TECDAX & MANZ AUTOMATION AG & DE000A0JQ5U3 & Not predicted \\
\hline 2015-09-03 & TECDAX & SILTRONIC AG NA O.N. & DE000WAF3001 & Wrongly predicted \\
\hline 2015-09-03 & TECDAX & QSC AG NA O.N. & DE0005137004 & Wrongly predicted \\
\hline 2015-06-03 & TECDAX & ADVA AG OPT.NETW.O.N. & DE0005103006 & Not predicted \\
\hline 2015-06-03 & TECDAX & BB BIOTECH NAM. SF 1 & CH0038389992 & Not predicted \\
\hline 2015-03-04 & TECDAX & GFT TECHNOLOGIES AG & DE0005800601 & Correctly predicted \\
\hline 2015-03-04 & TECDAX & KONTRON AG O.N. & DE0006053952 & Correctly predicted \\
\hline 2014-09-03 & TECDAX & RIB SOFTWARE AG NA & DE000A0Z2XN6 & Correctly predicted \\
\hline 2014-09-03 & TECDAX & PSI AG F.PR.U.SYS. NA & DE000A0Z1JH9 & Correctly predicted \\
\hline 2014-03-05 & TECDAX & MANZ AUTOMATION AG & DE000A0JQ5U3 & Not predicted \\
\hline
\end{tabular}

This table shows actual and predicted pro- and demotions within the DAX family. Correctly predicted changes refer to actual changes that were predicted by the forecasting model described in Sect. 2, not predicted refer to actual changes that were not predicted, and wrongly predicted refers to predicted changes that were not actual changes 
Table 13 Changes by Date (IV)

\begin{tabular}{|c|c|c|c|c|}
\hline Announcement date & Index & Stock & ISIN & Result \\
\hline 2014-03-05 & TECDAX & SOLARWORLD AG O.N. & DE000A1YCMM2 & Wrongly predicted \\
\hline 2014-03-05 & TECDAX & ADVA AG OPT.NETW.O.N. & DE0005103006 & Correctly predicted \\
\hline 2013-09-04 & TECDAX & NEMETSCHEK AG O.N. & DE0006452907 & Not predicted \\
\hline 2013-09-04 & TECDAX & COMPUGROUP HOL.AG O.N. & DE0005437305 & Not predicted \\
\hline 2013-09-04 & TECDAX & SUESS MICROTEC NA O.N. & DE000A1K0235 & Not predicted \\
\hline 2013-09-04 & TECDAX & EUROMICRON AG NA O.N. & DE000A1K0300 & Not predicted \\
\hline 2013-03-06 & TECDAX & TELEFONICA DTLD HLDG AG & DE000A1J5RX9 & Correctly predicted \\
\hline 2013-03-06 & TECDAX & SOLARWORLD AG O.N. KONV. & DE000A1YCMM2 & Not predicted \\
\hline 2013-03-06 & TECDAX & XING AG & DE000XNG8888 & Wrongly predicted \\
\hline 2012-09-05 & TECDAX & LPKF LASER+ELECTRON. & DE0006450000 & Correctly predicted \\
\hline 2012-09-05 & TECDAX & BB BIOTECH NAM. SF 1 & CH0038389992 & Not predicted \\
\hline 2012-09-05 & TECDAX & ARQUES INDUSTRIES AG & DE0005156004 & Correctly predicted \\
\hline 2012-09-05 & TECDAX & SINGULUS TECHNOL. EO 1 & DE000A1681X5 & Not predicted \\
\hline 2012-06-05 & TECDAX & SARTORIUS AG O.N. & DE0007165607 & Not predicted \\
\hline 2012-06-05 & TECDAX & CANCOM IT SYSTEME AG & DE0005419105 & Not predicted \\
\hline 2012-06-05 & TECDAX & CENTROTHERM PHOTOVOLT. & DE000A0JMMN2 & Not predicted \\
\hline 2012-06-05 & TECDAX & BB BIOTECH NAM. SF 1 & CH0038389992 & Not predicted \\
\hline 2012-03-05 & TECDAX & EUROMICRON AG NA O.N. & DE000A1K0300 & Not predicted \\
\hline 2012-03-05 & TECDAX & SARTORIUS AG VZO O.N. & DE0007165631 & Wrongly predicted \\
\hline 2012-03-05 & TECDAX & Q-CELLS SE & DE0005558662 & Correctly predicted \\
\hline 2011-09-05 & TECDAX & XING AG & DE000XNG8888 & Correctly predicted \\
\hline 2011-09-05 & TECDAX & PSI AG F.PR.U.SYS. NA & DE000A0Z1JH9 & Wrongly predicted \\
\hline 2011-09-05 & TECDAX & PHOENIX SOLAR AG O.N. & DE000A0BVU93 & Correctly predicted \\
\hline 2011-09-05 & TECDAX & ROTH + RAU O.N. & DE000A0JCZ51 & Correctly predicted \\
\hline 2011-03-03 & TECDAX & SUESS MICROTEC NA O.N. & DE000A1K0235 & Not predicted \\
\hline 2011-03-03 & TECDAX & ARQUES INDUSTRIES AG & DE0005156004 & Not predicted \\
\hline 2011-03-03 & TECDAX & SUESS MICROTEC O.N. & DE0007226706 & Wrongly predicted \\
\hline 2011-03-03 & TECDAX & CONERGY AG O.N. KONV. & DE000A1KRCK4 & Correctly predicted \\
\hline 2011-03-03 & TECDAX & MANZ AUTOMATION AG & DE000A0JQ5U3 & Not predicted \\
\hline 2011-03-03 & TECDAX & CONERGY AG O.N. & DE0006040025 & Wrongly predicted \\
\hline 2010-09-03 & TECDAX & ADVA AG OPT.NETW.O.N. & DE0005103006 & Correctly predicted \\
\hline 2010-09-03 & TECDAX & MEDIGENE NA O.N. & DE0005020903 & Correctly predicted \\
\hline
\end{tabular}

This table shows actual and predicted pro- and demotions within the DAX family. Correctly predicted changes refer to actual changes that were predicted by the forecasting model described in Sect. 2, not predicted refer to actual changes that were not predicted, and wrongly predicted refers to predicted changes that were not actual changes

\section{References}

Afego, P.N. 2017. Effects of changes in stock index compositions: A literature survey. International Review of Financial Analysis 52: $228-239$.

Barber, B.M., and T. Odean. 2008. All that glitters: The effect of attention and news on the buying behavior of individual and institutional investors. Review of Financial Studies 21(2): 785-818.

Beneish, M.D., and R.E. Whaley. 1996. An anatomy of the "S\&P game": The effects of changing the rules. The Journal of Finance 51(5): 1909-1930.

Biktimirov, E.N., and Y. Xu. 2019. Asymmetric stock price and investor awareness reactions to changes in the nasdaq 100 index. Journal of Asset Management 20(2): 134-145.
Blume, M.E., and R.M. Edelen. 2004. S\&p 500 indexers and tracking errors and liquidity. The Journal of Portfolio Management 30(3): 37-46.

Chakrabarti, R., W. Huang, N. Jayaraman, and J. Lee. 2005. Price and volume effects of changes in msci indices - nature and causes. Journal of Banking \& Finance 29(5): 1237-1264.

Chang, Y.-C., H. Hong, and I. Liskovich. 2014. Regression discontinuity and the price effects of stock market indexing. Review of Financial Studies 28(1): 212-246.

Chen, H., G. Noronha, and V. Singal. 2004. The price response to s\&p 500 index additions and deletions: Evidence of asymmetry and a new explanation. The Journal of Finance 59(4): 1901-1930.

Chen, H.-L., C.-Y. Shiu, and H.-S. Wei. 2016. Index reconstitutions and the role of foreign institutional investors on local corporate 
governance: Evidence from MSCI standard index. unpublished Working Paper.

Da, Z., J. Engelberg, and P. Gao. 2011. In search and of attention. The Journal of Finance 66(5): 1461-1499.

Deininger, C., C. Kaserer, and S. Roos. 2000. Stock price effects associated with index replacements in Germany. Unpublished.

Doeswijk, R.Q. 2005. The index revision party. International Review of Financial Analysis 14(1): 93-112.

Duffie, D. 2010. Presidential address: Asset price dynamics with slowmoving capital. The Journal of Finance 65(4): 1237-1267.

Fama, E.F., and K.R. French. 1993. Common risk factors in the returns on stocks and bonds. Journal of Financial Economics 33(1): 3-56.

Fernandes, M., and J. Mergulhao. 2016. Anticipatory effects in the ftse 100 index revisions. Journal of Empirical Finance 37: 79-90.

Gastineau, G.L. 2004. The benchmark index etf performance problem a simple solution. he Journal of Portfolio Management 30(2): 96-103.

Goetzmann, W.N., and M. Garry. 1986. Does delisting from the s\&p 500 affect stock price? Financial Analysts Journal 42(2): 64-69.

Green, T.C., and R. Jame. 2011. Strategic trading by index funds and liquidity provision around s\&p500 index additions. Journal of Financial Markets 14: 605-624.

Gromb, D., and D. Vayanos. 2010. Limits of arbitrage. Annual Review of Financial Economics 2(1): 251-275.

Harris, L., and E. Gurel. 1986. Price and volume effects associated with changes in the s\&p 500 list: New evidence for the existence of price pressures. The Journal of Finance 41(4): 815-829.

Jain, P.C. 1987. The effect on stock price of inclusion in or exclusion from the s\&p 500. Financial Analysts Journal 43(1): 58-65.

Kappou, K. 2018. The diminished effect of index rebalances. The Journal of Asset Management 19(4): 235-244.

Kappou, K., C. Brooks, and C. Ward. 2010. The s\&p500 index effect reconsidered: Evidence from overnight and intraday stock price performance and volume. Journal of Banking \& Finance 34(1): $116-126$.

Lee, C.I., K.C. Gleason, and J. Madura. 2008. Intraday and night index arbitrage. Quarterly Journal of Finance and Accounting 47(2): $3-16$.

Liu, S. 2006. The impacts of index rebalancing and their implications: Some new evidence from japan. Journal of International Financial Markets, Institutions and Money 16(3): 246-269.
Liu, S. 2011. The price effects of index additions: A new explanation. Journal of Economics and Business 63(2): 152-165.

Mase, B. 2007. The impact of changes in the ftse 100 index. The Financial Review 42(3): 461-484.

Mazouz, K., and B. Saadouni. 2007. The price effects of ftse 100 index revision: What drives the long-term abnormal return reversal? Applied Financial Economics 17(6): 501-510.

Nagel, S. 2012. Evaporating liquidity. The Review of Financial Studies 25(7): 2005-2039.

Petajisto, A. 2011. The index premium and its hidden cost for index funds. Journal of Empirical Finance 18(2): 271-288.

Qiu, M., and J. Pinfold. 2007. Price and trading volume reactions to index constitution changes. Managerial Finance 34(1): 53-69.

Shleifer, A. 1986. Do demand curves for stocks slope down? The Journal of Finance 41(3): 579-590.

Song, M.H., and R.A. Walkling. 2000. Abnormal returns to rivals of acquisition targets: A test of the acquisition probability hypothesis. Journal of Financial Economics 55(2): 143-171.

Welch, B.L. 1938. The significance and of the difference and between two and means when the population and variances are and unequal. Biometrika 29(3-4): 350-362.

Wilcoxon, F. 1945. Individual comparisons by ranking methods. Biometrics Bulletin 1(6): 80-83.

Yu, S., G. Webb, and K. Tandon. 2015. What happens when a stock is added to the nasdaq-100 index? what doesn't happen? Managerial Finance 41(5): 480-506.

Yun, J., and T.S. Kim. 2010. The effect of changes in index constitution: Evidence from the korean stock market. International Review of Financial Analysis 19(4): 258-269.

Zdorovtsov, V., X. Tang, and Z. Onayev. 2017. Predatory trading around russell reconstitution. Unpublished Working Paper.

Publisher's Note Springer Nature remains neutral with regard to jurisdictional claims in published maps and institutional affiliations.

Friedrich-Carl Franz graduated with a master's degree in finance from the University of Mannheim and is now a Ph.D. candidate in finance at the University of Frankfurt. Before starting his Ph.D., he worked as a portfolio manager for a large Swiss asset manager. 